\title{
The $\mathrm{SCF}^{\boldsymbol{\beta} \text {-TRCP}}$-ubiquitin ligase complex associates specifically with phosphorylated destruction motifs in I $\mathrm{I} B \boldsymbol{\alpha}$ and $\beta$-catenin and stimulates $I_{\kappa} B \alpha$ ubiquitination in vitro
}

\author{
Jeffrey T. Winston, ${ }^{1,5}$ Peter Strack, ${ }^{4,5}$ Peggy Beer-Romero, ${ }^{4}$ Claire Y. Chu, ${ }^{1}$ Stephen J. Elledge, ${ }^{1-3}$ \\ and J. Wade Harper ${ }^{1,6}$ \\ ${ }^{1}$ Verna \& Marrs McLean Department of Biochemistry, ${ }^{2}$ Department of Molecular and Human Genetics, ${ }^{3}$ Howard Hughes \\ Medical Institute, Baylor College of Medicine, Houston, Texas 77030 USA; ${ }^{4}$ Mitotix, Inc., \\ Cambridge, Massachusetts 02139 USA
}

Ubiquitin-mediated proteolysis has a central role in controlling the intracellular levels of several important regulatory molecules such as cyclins, CKIs, p53, and IкB $\alpha$. Many diverse proinflammatory signals lead to the

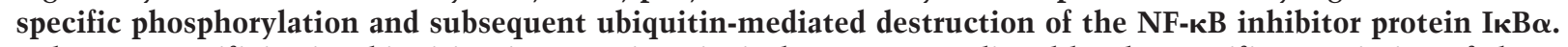
Substrate specificity in ubiquitination reactions is, in large part, mediated by the specific association of the E3-ubiquitin ligases with their substrates. One class of E3 ligases is defined by the recently described SCF complexes, the archetype of which was first described in budding yeast and contains $\underline{S} \mathrm{kp} 1, \underline{\mathrm{Cdc}} 53$, and the F-box protein Cdc4. These complexes recognize their substrates through modular F-box proteins in a phosphorylation-dependent manner. Here we describe a biochemical dissection of a novel mammalian SCF complex, SCF ${ }^{\beta-T R C P}$, that specifically recognizes a 19-amino-acid destruction motif in IKB $\alpha$ (residues 21-41) in a phosphorylation-dependent manner. This SCF complex also recognizes a conserved destruction motif in $\beta$-catenin, a protein with levels also regulated by phosphorylation-dependent ubiquitination. Endogenous I $\mathbf{B} \alpha$-ubiquitin ligase activity cofractionates with $S_{C F^{\beta-T R C P}}$. Furthermore, recombinant $\mathrm{SCF}^{\beta-T R C P}$ assembled in mammalian cells contains phospho-IкB $\alpha$-specific ubiquitin ligase activity. Our results suggest that an $S_{C F}{ }^{\beta-T R C P}$ complex functions in multiple transcriptional programs by activating the NF- $\kappa$ B pathway and inhibiting the $\beta$-catenin pathway.

[Key Words: Ubiquitin ligase; SCF complex; proteolysis; destruction motifs; NF-кB; $\beta$-catenin]

Received December 3, 1998; revised version accepted December 30, 1998.

The transcription factor NF- $\mathrm{kB}$ has a central role in cellular stress and inflammatory responses by controlling cytokine-inducible gene expression and lymphocyte stimulation by antigens (Baeuerle and Baltimore 1996; Gilmore et al. 1996). In addition, NF-кB is required to block cell death in response to tumor necrosis factor $\alpha$ $(\mathrm{TNF} \alpha)$ and ionizing radiation, suggesting that it acts to regulate the transcription of survival genes (Beg and Baltimore 1996; Liu et al. 1996; Van Antwerp et al. 1996; Wang et al. 1996). NF-кB is a ubiquitous heterodimeric complex composed of a p65/RelA subunit and a p50 subunit. This complex is normally sequestered in an inactive form in the cytoplasm through interaction with members of a family of inhibitory proteins, the IкBs (Beg et al. 1992; for review, see Baeuerle and Baltimore 1996). These proteins, when associated with NF-кB, obscure

\footnotetext{
${ }^{5}$ Co-first authors.

${ }^{6}$ Corresponding author.

E-MAIL jharper@bcm.tmc.edu; FAX (713) 796-9438.
}

the nuclear localization signal in NF-кB and also block the ability of NF- $\mathrm{BB}$ to bind DNA. In response to TNF $\alpha$ and other signals, I $\mathrm{I} \mathrm{B} \alpha$ is rapidly phosphorylated on two serine residues near the amino terminus (Ser-32 and Ser36 in IкB $\alpha$ ) (Beg et al. 1993; Finco et al. 1994; Alkalay et al. 1995; Brown et al. 1995; Chen et al. 1995, 1996; DiDonato et al. 1995; Lin et al. 1995). This modification triggers the rapid destruction of IкB $\alpha$ by ubiquitin-mediated proteolysis, thereby allowing NF- $\mathrm{kB}$ nuclear translocation and target gene expression (Chen et al. 1995; Scherer et al. 1995; for review, see Hochstrasser 1996). Recent work has uncovered two IкB $\alpha$ kinases, Iк $\mathrm{K} \alpha$ and IкK $\beta$, that are responsible for signal-dependent phosphorylation of IкB $\alpha$ (DiDonato et al. 1997; Mercurio et al. 1997; Regnier et al. 1997; Woronicz et al. 1997; Zandi et al. 1997, 1998). These proteins are part of a $700-\mathrm{kD}$ protein complex that is assembled through two structural components IкK $\gamma / \mathrm{NEMO}$ and IKAP (Cohen et al. 1998; Rothwarf et al. 1998; Yamaoka et al. 1998) and are activated by cytokines. In vitro, both IкK $\alpha$ and IкK $\beta$ can 
phosphorylate $\mathrm{I}_{\kappa} \mathrm{B} \alpha$ specifically on serines 32 and 36 , but both kinases are required for efficient Iк $\mathrm{B} \alpha$ phosphorylation in vivo (Zandi et al. 1997).

Although the pathways leading to IкB $\alpha$ phosphorylation have been described in detail, little is known about the molecules responsible for ubiquitination. Ubiquitinmediated proteolysis involves a cascade of ubiquitin transfer reactions in which the ubiquitin-activating enzyme E1 uses ATP to form a high-energy thiolester bond with ubiquitin, which is then transferred to members of the E2 ubiquitin-conjugating enzyme family (Hershko et al. 1983; Hochstrasser 1995). Ubiquitin is then transferred from the E2 to lysine residues in the target through an E3-ubiquitin ligase. E3s serve as adaptors that interact with both the target protein and the appropriate E2, thereby providing specificity to the ubiquitin transfer reaction. In some cases, the E3 is also involved in ubiquitin transfer (Scheffner et al. 1995; Rolfe et al. 1995). Multiple rounds of ubiquitination of the initial conjugates lead to polyubiquitination, which targets the protein for proteolysis by the 26S proteasome. Recent studies have elaborated a modular ubiquitin ligase complex, the SCF-ubiquitin ligase, which mediates phosphorylation-dependent ubiquitination of a large number of proteins (for review, see Elledge and Harper 1998; Patton et al. 1998b). The SCF is composed of Skp1, Cdc53/ Cull, and a specificity-conferring F-box protein (Bai et al. 1996; Feldman et al. 1997; Skowyra et al. 1997; Patton et al. 1998a). F-box proteins contain two domains, an F-box motif that binds Skp1 and allows assembly into Skp1/ Cdc53 complexes, and a second protein-protein interaction domain that interacts specifically with one or more target proteins (Bai et al. 1996). Cdc53/Cul1, in turn, interacts with both the E2 and the Skp1/F-box protein complex (Skowyra et al. 1997; Patton et al. 1998a). SCF complexes mediate phosphorylation-dependent destruction of a wide array of regulatory proteins in yeast, including the Cdk inhibitors Sic1, Far1, and Rum1, G 1 cyclins, the transcription factor Gcn 4 , and the DNA replication initiator proteins Cdc6 and Cdc18 (for review, see Elledge and Harper 1998; Patton et al. 1998b). In contrast with yeast, targets of vertebrate SCF complexes remain largely unknown. Previously, we identified four vertebrate proteins that contain the F-box motif, linking them to the ubiquitin pathway: mammalian cyclin F, Skp2, MD6, and Xenopus $\beta$-TRCP (్-transducin repeat-containing protein; Bai et al. 1996). $\beta$-TRCP was originally identified as a suppressor of a temperature-sensitive mutation in the budding yeast CDC15 gene (Spevak et al. 1993), but its mechanism of suppression has not been determined. Recent genetic evidence has implicated Xenopus $\beta$-TRCP and its Drosphila homolog, slimb, in control of proteolysis in the Hedgehog and Wingless/ Wnt signaling pathways (Jiang and Struhl 1998; Marikawa and Elinson 1998).

We have used biochemical approaches to examine whether I $\mathrm{KB} \alpha$ ubiquitination might involve an SCFubiquitin ligase. Here we report that mammalian $\beta$-TRCP binds to the IкB $\alpha$ destruction motif in a phosphorylation-dependent manner, thereby recruiting IкB $\alpha$ into an SCF-ubiquitin ligase complex. Moreover, $\mathrm{SCF}^{\beta-T R C P}$ components cofractionate with IкB $\alpha-u b i-$ quitin ligase activity from tissue culture cells and $\mathrm{SCF}^{\beta-T R C P}$ can stimulate ubiquitination of phosphorylated but not unphosphorylated IкB $\alpha$ in an in vitro reconstitution assay. We also demonstrate that the same $\mathrm{SCF}^{\beta-T R C P}$ complex recognizes a similar destruction motif in $\beta$-catenin, a component of the TCF/Lef transcription factor complex that functions downstream of Wingless/Wnt (for review, see Peifer 1997) and whose levels are also controlled by phosphorylation-dependent ubiquitin-mediated proteolysis (Aberle et al. 1997). Our results, together with the effects of loss-of-function mutations in the Drosophila $\beta$-TRCP homolog slimb (Jiang and Struhl 1998), suggest that a single SCF ${ }^{\beta-T R C P}$ complex functions in diverse signaling pathways that impinge on transcription control mediated by cytokines (NF-кB), Wnt/Wingless ( $\beta$-catenin), and Hedgehog [Cubitus interruptus (Ci)].

\section{Results

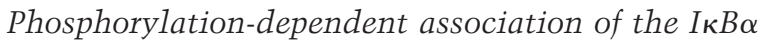 destruction motif with Skp1}

Iк $\mathrm{B} \alpha$ contains two serine residues at positions 32 and 36 that are specifically phosphorylated by the IкK complex in response to TNF $\alpha$ stimulation. Phosphorylation of both of these residues is required for $\mathrm{I}_{\kappa} \mathrm{B} \alpha$ ubiquitination in vivo. Previous studies have shown that a 21-aminoacid phosphopeptide containing this destruction motif can block IкB $\alpha$-ubiquitin ligase activity in crude cell extracts and can block NF- $\kappa \mathrm{B}$ activation in tissue culture cells (Yaron et al. 1997). In addition, this destruction motif can confer signal-dependent destruction when fused to heterologous proteins (Wulczyn et al. 1998). Given the role for SCF complexes in phosphorylationdependent ubiquitination of various regulatory proteins, we sought to determine whether SCF complexes might be involved in IкB $\alpha$ ubiquitination. Synthetic 21-residue peptides encompassing the $\mathrm{I} \kappa \mathrm{B} \alpha$ destruction motif in either the doubly phosphorylated or unphosphorylated forms (Fig. 1a) were immobilized on agarose beads and incubated with HeLa cell lysates. Proteins stably associated with these beads were then examined for the presence of Skp1 by immunoblotting (Fig. 1b). Skp1 was readily detected in proteins bound to the phospho-ІкB $\alpha$ peptide but not the unphosphorylated peptide. We estimate that $\sim 1 \%$ of the total Skp1 in these lysates stably associated with the phospho-IкB $\alpha$ peptide under these conditions.

\section{Recognition of phosphorylated destruction motifs in $I \kappa B \alpha$ and $\beta$-catenin by the WD-40 repeat-containing F-box protein $\beta$-TRCP}

The ability of a phospho-IкB $\alpha$ peptide to associate with Skp1 suggested the existence of an F-box protein capable of recognizing the IкB $\alpha$ destruction motif. Our previous studies identified three vertebrate F-box proteins (Skp2, 
a

Figure 1. The F-box protein $\beta$-TRCP associates with phosphorylated destruction motifs in I $\mathrm{B} \alpha$ and $\beta$-catenin. (a) Sequences of the IкB $\alpha$ (p21) and $\beta$-catenin peptides used in this study. The positions of phosphorylation in the peptides are shown as is the consensus sequence for the destruction motif. ( $\phi)$ Hydrophobic amino acid. (b) Phosphorylation-specific association of the IкB $\alpha$ destruction motif with Skp1 in vitro. HeLa cell proteins $(600 \mu \mathrm{g})$ were incubated with phosphorylated or unphosphorylated IкB $\alpha$ peptides (p21) immobilized on beads. Bound proteins were immunoblotted with anti-Skp1 antibodies. Approximately 1\% of the Skpl contained in these lysates remained bound to the phosphorylated IкB $\alpha$ beads. (c) $\beta$-TRCP specifically associated with phosphorylated IкB $\alpha$ and $\beta$-catenin destruction motifs. A panel of $\left[{ }^{35} \mathrm{~S}\right]$ methionine-labeled in vitro-translated F-box proteins was used in binding reactions with IкB $\alpha$ (lanes 1-3) or $\beta$-catenin (lanes 4-6) peptide beads. Bound proteins were analyzed by SDS-PAGE and autoradiography. (Right) The domain structures of each F-box protein. (d) The pattern of expression of $\beta$-TRCP at day 11.5 during mouse development was determined by in situ hybridization. The dark-field signal from the $\beta$-TRCP riboprobe is shown in red. (hb) Hindbrain; (fb) forebrain; (h) heart; (1) lung; (li) liver. (e) Chromosomal localization of $\beta$-TRCP. A bacmid containing human $\beta$-TRCP DNA was hybridized to metaphase chromosomes (blue) and detected using fluorescein. The position of hybridization (yellow) is $10 \mathrm{q} 24$ (indicated by arrows). ( $f$ ) $\beta$-TRCP is localized in the cytoplasm. HeLa cells were transiently transfected with pCMV-HA- $\beta$-TRCP and subcellular localization determined after $48 \mathrm{hr}$ by indirect immunofluorescence. Anti-HA localization, red; nuclei stained with DAPI, blue.

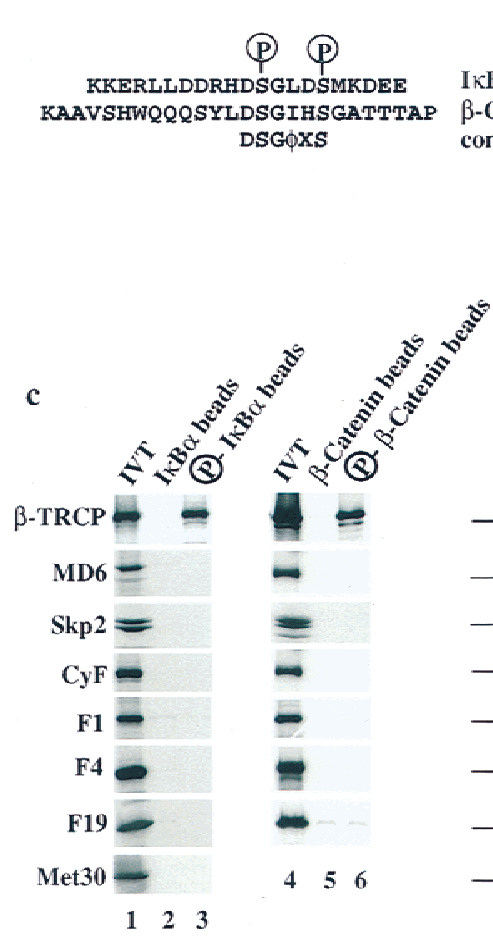

$\kappa \mathrm{B} \alpha(21-41)$ -Catenin (19-44) consensus b

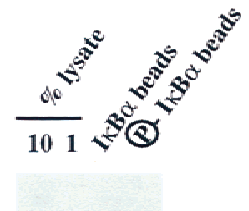

Skp1 -

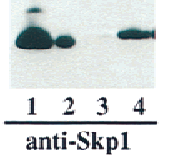

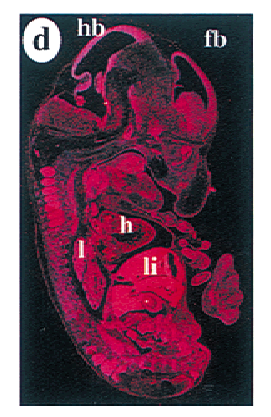
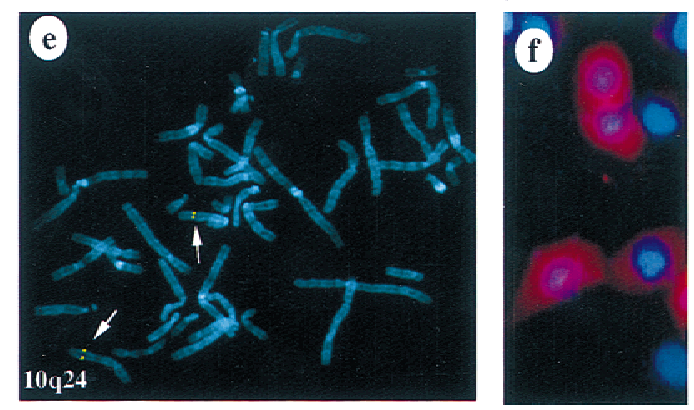

MD6, and Xenopus $\beta$-TCRP) based on homology to the F-box sequence in human cyclin $\mathrm{F}$ and the budding yeast protein Cdc4 (Bai et al. 1996). Recently, we have identified cDNAs encoding 20 distinct mouse and/or human F-box proteins, including the WD-40 repeat-containing protein $\beta$-TRCP, a leucine-rich repeat containing F-box protein $\mathrm{F} 1$, and a number of F-box proteins lacking known protein-protein interaction motifs outside the Fbox (Fig. 1c; J. Winston, S.J. Elledge, and J.W. Harper, in prep.). Using in vitro translation products, we asked whether members of a collection of these F-box proteins could associate with IкB $\alpha$ peptides. Only one, $\beta$-TRCP, was found to associate with the phospho-IкB $\alpha$ destruction motif, and this interaction was dependent on phosphorylation (Fig. 1c). Mouse and human $\beta$-TRCP are $95 \%$ identical and both interact equally well with IкB $\alpha$ in this assay (data not shown for human $\beta$-TRCP). Our analysis included two other WD-40-containing F-box proteins, human MD6 and Met30, the closest homolog of $\beta$-TRCP in budding yeast ( $31 \%$ identity). Importantly, neither of these proteins associated with phospho-IкB $\alpha$ (Fig. 1c), suggesting that the interaction of $\beta$-TRCP with phospho-IкB $\alpha$ is highly specific.

Previous studies in Drosophila have demonstrated that mutations in the $\beta$-TRCP homolog slimb led to accumulation of Armadillo, the Drosophila homolog of $\beta$-catenin (Jiang and Struhl 1998). $\beta$-Catenin is known to be ubiquitinated in a glycogen synthase kinase $3 \beta$ (GSK3 $\beta$ )-dependent manner and contains a motif within a cluster of candidate GSK3 $\beta$ phosphorylation sites that is closely related to the IкB $\alpha$ destruction motif (Fig. 1a; Ikeda et al. 1998). Although the GSK3 $\beta$ phosphorylation sites in $\beta$-catenin are not known, we hypothesized based on the sequence similarity between IкB $\alpha$ and $\beta$-catenin that Ser-33 and Ser-37 might represent relevant phosphorylation sites. A $\beta$-catenin-derived peptide containing phosphoserine residues at these two positions associated with $\beta$-TRCP but not other F-box proteins tested, 
whereas the unphosphorylated peptide failed to associate with $\beta$-TRCP (Fig. 1c).

$\mathrm{NF}-\kappa \mathrm{B}$ is a ubiquitous transcription factor. As assessed by in situ hybridization, $\beta$-TRCP is also expressed throughout the developing mouse embryo (day 11.5 postcoitum), with the highest levels in the brain, lung, and liver (Fig. 1d). $\beta$-TRCP is largely, if not exclusively, cytoplasmic, as assessed in HeLa cells transiently expressing an HA-tagged $\beta$-TRCP protein (Fig. 1f). The gene for human $\beta$-TRCP lies on chromosome 10q24, as determined by in situ hybridization of metaphase chromosomes with $\beta$-TRCP genomic DNA (Fig. 1e). Cytogenetic data indicate that this region of the genome is altered in a limited number of cancer types (see Discussion).

\section{Association of SCF $F^{\beta-T R C P}$ with $I \kappa B \alpha$ and $\beta$-catenin destruction motifs}

Having identified $\beta$-TRCP as a candidate F-box protein for IкB $\alpha$ and $\beta$-catenin, we next sought to demonstrate that $\beta$-TRCP forms an SCF complex in mammalian cells and that this complex recognizes IкB $\alpha$ and $\beta$-catenin destruction motifs. Although there are six mammalian Cullin homologs, the interaction of Skp1 with this family appears to be restricted to Cull (Michel and Xiong 1998). 293 T cells were transfected with various combinations of plasmids expressing epitope-tagged $\beta$-TRCP,
Cul1, or Skp1 and anti-Myc immune complexes from cell lysates analyzed by immunoblotting. $\beta$-TRCP ${ }^{\mathrm{Myc}}$ associated with both transfection-derived Skp1 ${ }^{\mathrm{HA}}$ (Fig. 2a, lanes 4,5) and Cul1 ${ }^{\mathrm{HA}}$ (lane 5). In contrast, Cul1 ${ }^{\mathrm{HA}}$ and $S k p 1^{\mathrm{HA}}$ were not precipitated from control lysates lacking $\beta$-TRCP ${ }^{\mathrm{Myc}}$ (lane 6). In the absence of transfection of Skp1 and Cul1, $\beta$-TRCP ${ }^{\mathrm{Myc}}$ associated with endogenous Skp1 (lane 3) and Cul1 (data not shown). Analogous results were obtained when $\mathrm{Cull}^{\mathrm{HA}}$ was immunoprecipitated with anti-HA antibodies from cells expressing $\mathrm{Cul1}^{\mathrm{HA}}, \beta-\mathrm{TRCP}^{\mathrm{Myc}}$, and $\mathrm{Skp}^{\mathrm{Myc}}$ (Fig. 2c). Thus, $\beta$-TRCP can form an SCF complex in vivo analogous to that found previously for other F-box proteins (Skowyra et al. 1997; Lisztwan et al. 1998; Lyapina et al. 1998; Michel and Xiong 1998).

Next, we asked whether the $\mathrm{SCF}^{\beta-\mathrm{TRCP}}$ complex could associate with the IкB $\alpha$ destruction motif peptide. As shown in Figure $3 a$, the $\mathrm{SCF}^{\beta-\mathrm{TRCP}}$ complex readily associated with phosphorylated I $\mathrm{K} B \alpha$ peptide beads (lanes $6,8,10$ ) but was not retained on unphosphorylated ІкB $\alpha$ beads (lanes 5,7,9). Although Cull associates at low levels with agarose beads containing I $\mathrm{K} B \alpha$ peptides in the absence of $\beta$-TRCP ${ }^{\mathrm{Myc}}$ expression $($ lanes 11,12 ) and with agarose beads alone (data not shown), the association with the phospho-ІкB $\alpha$ peptide was greatly enhanced by expression of $\beta$-TRCP ${ }^{\mathrm{Myc}}$ (lane 10). Consistent with the results in Figure 1b, endogenous Skp1 was observed in

a

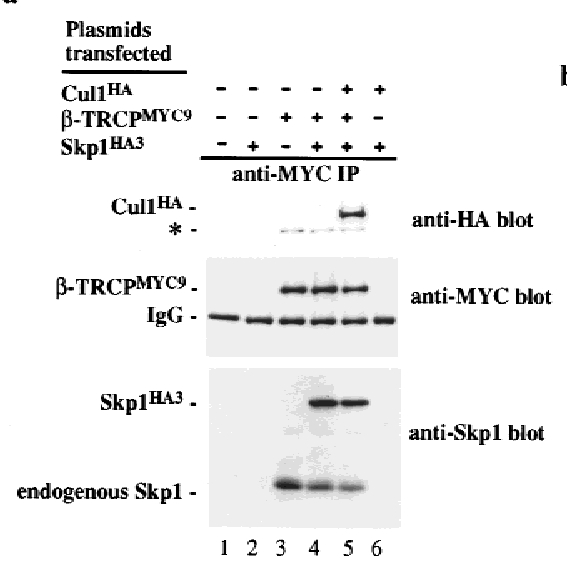

b

Plasmids

transfected

$\overline{\mathrm{Cul1}^{\mathrm{HA}}}$ - - . +

B-TRCPMYC9 --+++

Skp1 $^{\mathrm{HA} 3} \quad \frac{+-+++}{\text { lysates }}$

lysates
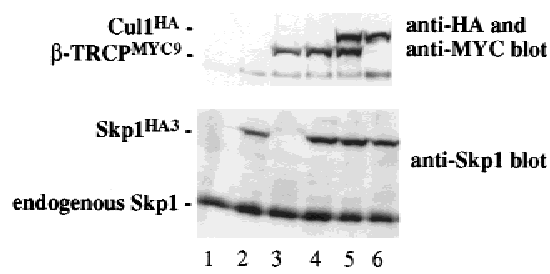

c

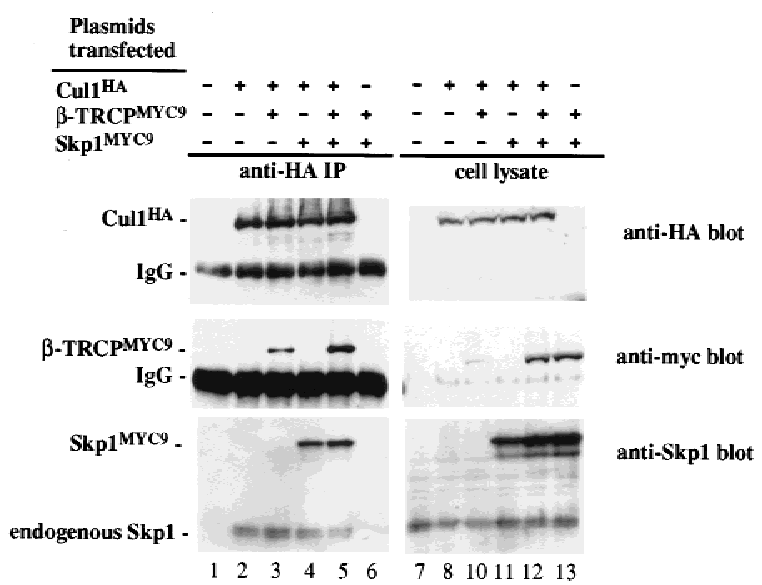

Figure 2. $\beta$-TRCP associates with Skp1 and Cull in tissue culture cells. $293 \mathrm{~T}$ cells were transfected with the indicated plasmids and lysates $(0.5 \mu \mathrm{g}$ of protein $/ 250 \mu \mathrm{l})$ used for immunoprecipitation as described in Materials and Methods. Immune complexes or crude lysates from each transfection were analyzed for the presence of Skp1, Cull, and $\beta$-TRCP by immunoblotting. (a) Anti- $\beta$-TRCP ${ }^{\mathrm{Myc}}$ immune complexes. Blots were probed first for $\beta$-TRCP, stripped, and probed for Skp1 and Cul1. The bands indicated by the asterisk indicate the position of $\beta$-TRCP whose antibody was not efficiently stripped from the blot. (b) Crude cell lysates $(50 \mu \mathrm{g})$ corresponding to extracts used in $a$. (c) Anti-Cul1 ${ }^{\mathrm{HA}}$ immune complexes (lanes 1-6) and corresponding cell lysates $(50 \mu \mathrm{g})$ (lanes 7-13). The positions of both epitopetagged and endogenous Skp1 are shown. 
a

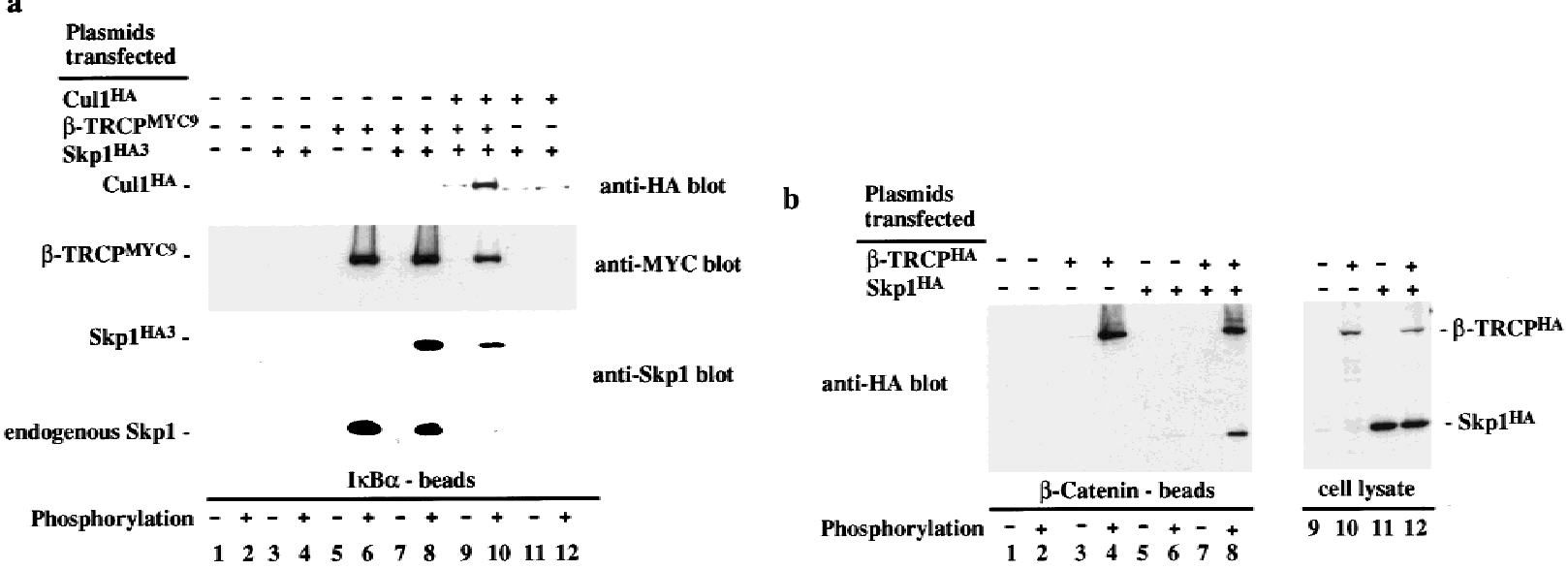

Figure 3. Association of $\mathrm{SCF}^{\beta-\mathrm{TRCP}}$ with $\mathrm{I}_{\kappa} \mathrm{B} \alpha$ and $\beta$-catenin destruction motifs and with the

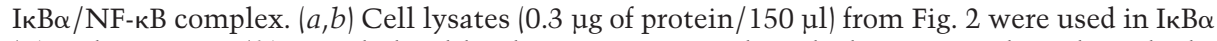
$(a)$ and $\beta$-catenin $(b)$ peptide bead binding reactions as described in Materials and Methods. Bound proteins were analyzed by immunoblotting with the indicated antibodies. $(c)$ Phosphorylation-dependent association of $\beta-\mathrm{TRCP}^{\mathrm{Myc}}$ with the ІкB $\alpha / \mathrm{p} 50 / \mathrm{p} 65$ complex in vitro. $\beta$-TRCP ${ }^{\mathrm{Myc}}$ immune complexes (lanes 2,5) corresponding to those in Fig. 2a (lane 3) or control complexes (lanes 3,6) corresponding to those in Fig. 2a (lane 1) were used in binding reactions

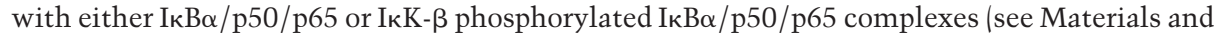
Methods). Bound proteins were separated by SDS-PAGE and immunoblotted using anti-p50 or anti-IкB $\alpha$ antibodies. The asterisk (lanes 1,4) indicates the positions of $15 \%$ of the input IкB $\alpha$ complexes used in the binding reaction.

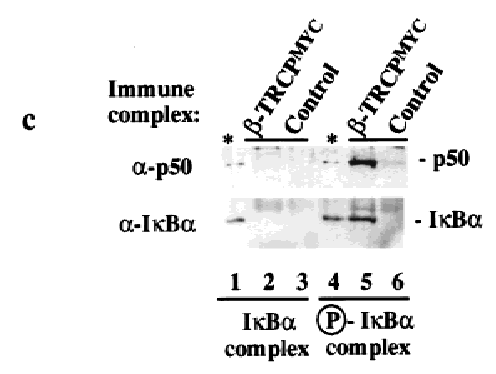

association with phospho-ІкB $\alpha$ peptide beads in a phosphorylation-dependent manner in the absence of transfection of $\beta$-TRCP (lanes 1-4), but when the levels of $\beta$-TRCP were increased by transfection, the quantity of endogenous Skp1 associated with $\beta$-TRCP increased substantially (Fig. 3a, lanes 4,6). Analogous results were obtained in a more limited series of binding reactions employing $\beta$-catenin-derived peptides (Fig. 3b).

Although it was clear that destruction motif peptides can bind the SCF ${ }^{\beta \text {-TRCP }}$ complex, it was necessary to demonstrate that this complex also recognized the endogenous ubiquitination substrate, the IкK-phosphorylated IкB $\alpha / \mathrm{NF}-\kappa \mathrm{B}$ complex. To generate this substrate, ІкB $\alpha / \mathrm{p} 50 / \mathrm{p} 65$ complexes were produced in insect cells and purified to near homogeneity (Fig. 4a). When incubated with ATP and purified IкK- $\beta$, the IкB $\alpha$ protein underwent a mobility shift reminiscent of that observed upon phosphorylation in vivo, and this phosphorylated Iк $B \alpha$ protein was recognized by phosphospecific antibodies directed at Ser-32 of IкB $\alpha$ (Fig. $4 b$, lane 2). In addition, microsequencing of ІкK-treated ІкB $\alpha$ confirmed that both Ser-32 and Ser-36 were phosphorylated (data not shown). To examine whether SCF ${ }^{\beta-T R C P}$ could recognize this complex, binding reactions were performed using immobilized $\mathrm{SCF}^{\beta-\mathrm{TRCP}}$ complexes isolated from $293 \mathrm{~T}$ cells transiently expressing Myc-tagged $\beta$-TRCP or mock transfected cells as a control and either phosphorylated or unphosphorylated IкB $\alpha / N F-\kappa B$ complexes. The $\beta$-TRCP ${ }^{\mathrm{Myc}}$ immune complexes contain endogenous Skp1 (Fig. 2, lane 3) and Cul1 (data not shown) as determined by immunoblotting. Both I $\mathrm{I} B \alpha$ and p50 were found to associate with the $\mathrm{SCF}^{\beta-\mathrm{TRCP}}$ complex but not control immune complex in a phosphorylation-dependent manner (Fig. 3c). Similar results were obtained with GST- $\beta$-TRCP complexes purified from insect cells (data not shown).

\section{Biochemical association of endogenous $I_{\kappa} B \alpha$-ubiquitin ligase activity with $\beta$-TRCP}

Crude cell lysates from the human monocyte cell line THP. 1 contain potent I $\mathrm{K} \mathrm{B} \alpha$-ubiquitin ligase activity (Fig. $4 c)$. In the context of an IкB $\alpha / N F-\kappa B$ complex, efficient IкB $\alpha$ ubiquitination by these lysates is dependent on phosphorylation by IкK (Fig. 4c). As reported earlier (Yaron et al. 1997), this IкB $\alpha$-ubiquitin ligase activity is strongly inhibited by phosphorylated I $\mathrm{K} \alpha \alpha$ destruction motif peptides (Fig. 4d, lanes 4,5 ) but not by nonphosphorylatable destruction box peptides (lanes 2,3). Thus, this assay reiterates the requirements for IкB $\alpha$ ubiquitination observed in vivo. Greater than $95 \%$ of the IкB $\alpha-$ ubiquitin ligase activity in these extracts can be precipitated with $30 \%-50 \%$ ammonium sulfate (Fig. $4 \mathrm{e}$, lane 1) and can be further purified by chromatography on a phenyl-Sepharose column (Fig. 4e; see Materials and Methods). Peak fractions of IкB $\alpha$-ubiquitin ligase activity (Fig. $4 \mathrm{e}$, lanes 8,9 ) elute at $0.5 \mathrm{~m}$ ammonium sulfate.

Having partially purified components of the IкB $\alpha-$ ubiquitin ligase, we examined whether $\beta$-TRCP and other SCF components were contained in active fractions from the phenyl-Sepharose column. Skp1 has an extended elution profile, but both Skp1 and Cull are contained in the active fractions 7 and 8 (Fig. 4e). Skp1 and Cull can interact with multiple F-box proteins, and 

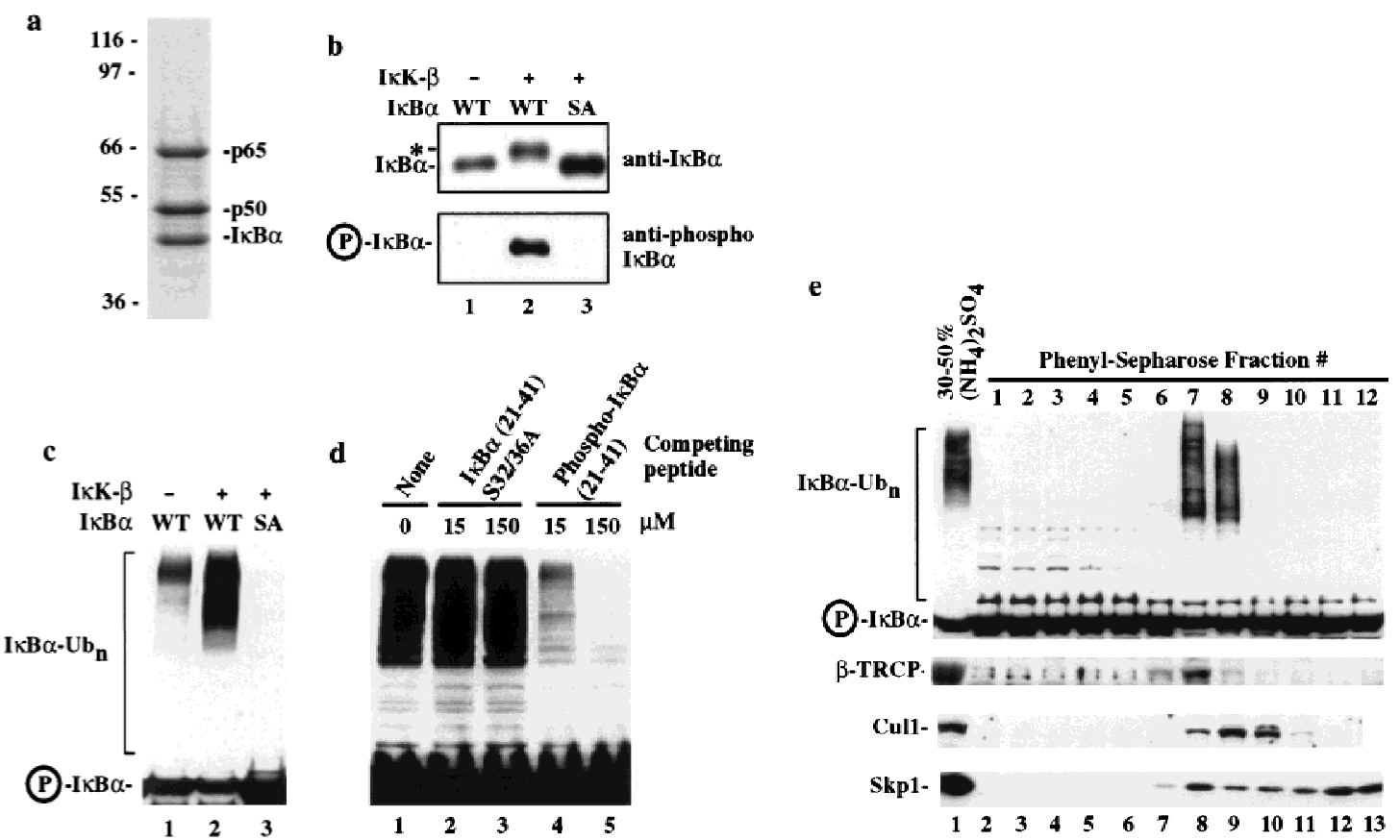

Figure 4. IкB $\alpha$-ubiquitin ligase activity from human cells cofractionates with $\beta$-TRCP. (a) IкB $\alpha / \mathrm{p} 50 / \mathrm{p} 65$ complexes were purified to near homogeneity from insect cells as described in Materials and Methods. Proteins were separated by SDS-PAGE and stained with Coomassie blue. (b) Phosphorylation of the IкB $\alpha / \mathrm{p} 50 / \mathrm{p} 65$ complex by IкK- $\beta$. The IкB $\alpha$ complex (lanes 1,2) or a nonphosphorylatable IкB $\alpha$ mutant (S32/36A) complex (lane 3) was incubated in the presence of ATP and IкK- $\beta$ as indicated in Materials and Methods. Products were analyzed by immunoblotting with anti-Iк $\mathrm{B} \alpha$ antibodies to detect a mobility shift accompanying phosphorylation that is absent in the nonphosphorylatable mutant $(t o p)$ or with antibodies that specifically detect the Ser-32-phosphorylated form of IкB $\alpha$ (bottom). (c) Ubiquitination of IкB $\alpha$ complexes by crude cell lysates was performed as described in Materials and Methods. Phosphorylation leads to a 10 - to 20 -fold increase in ubiquitin conjugates relative to the unphosphorylated complex, whereas no activity is observed with the nonphosphorylatable ІкB $\alpha$ complexes. (d) Inhibition of ІкB $\alpha$ ubiquitination by phosphorylated IкB $\alpha$ destruction motif peptides but not by nonphosphorylatable destruction motif peptides (p19). Ubiquitination reactions were performed with crude cell extracts and IкK- $\beta$ phosphorylated IкB $\alpha$ complexes in the presence or absence of phosphorylated or nonphosphorylatable destruction motif peptides. Specific inhibition of ubiquitination was observed with the phosphorylated peptide. $(e)$ Cofractionation of $\beta$-TRCP with endogenous IкB $\alpha$-ubiquitin ligase activity. Crude extracts from THP.1 cells were precipitated with ammonium sulfate. Solubilized proteins containing ubiquitin ligase activity were fractionated using a phenyl-Sepharose column and activity in each fraction determined as described in Materials and Methods. Aliquots of column fractions were assayed for $\beta$-TRCP, Cul1, and Skp1 by immunoblotting. Fractions containing $\beta$-TRCP, Cul1, and Skp1 (fractions 7,8) contain IкB $\alpha$-ubiquitin ligase activity.

the identity of the F-box protein in complexes with Cull and Skp1 is likely to affect elution properties on phenylSepharose. In contrast with Skp1, $\beta$-TRCP levels peak in fraction 7 , as determined using affinity-purified carboxyterminal antibodies, coincident with maximal activity (Fig. 4e, lane 8). $\beta$-TRCP was also detected in active fraction 8 (Fig. 4e, lane 9). This fraction contained lower levels of I $\kappa \mathrm{B} \alpha$-ubiquitin ligase activity, as assessed by the extent of conjugation, consistent with the lower levels of $\beta$-TRCP. As shown below, under some gel conditions the $\beta$-TRCP protein is resolved into a closely spaced doublet of proteins at $58-60 \mathrm{kD}$. Interestingly, although fraction 6 contains detectable levels of Skp1 and $\beta$-TRCP, it lacks detectable Cull and IкB $\alpha$-ubiquitin ligase activity (Fig. 4e, lane 7). Likewise, fraction 9 containing Skp1 and Cul1 but no $\beta$-TRCP is also inactive (Fig. 4e, lane 10).

Consistent with a role for Skp1 in the I $\mathrm{KB} \alpha$-ubiquitin ligase, antibodies against Skp1, but not control GST antibodies, deplete Iк $B \alpha$-ubiquitin ligase activity from the active phenyl-Sepharose fractions (Fig. 5a). As expected, Skp1 and Cull are largely depleted from these active extracts (lane 2). Importantly, the majority of $\beta$-TRCP is also removed by Skp1 antibodies (Fig. 5a, lane 2). $\beta$-TRCP migrated as a closely spaced doublet at 58 and $60 \mathrm{kD}$. The faster migrating form, corresponding to $\sim 80 \%$ of the total, was essentially depleted by anti-Skp1 antibodies (lane 2), when compared with control GSTdepleted extracts. The source of the heterogeneity in $\beta$-TRCP is not known at present, but it is possible that the more slowly migrating form is not associated with Skp1 or is dislodged from Skp1 by the anti-Skp1 antibodies. We also note that Cull migrated as a doublet (Fig. 5a). The slower migrating form is likely to correspond to a form of the protein conjugated to NEDD8, a homolog of Rub1 that is known to be covalently linked to Cdc53 in budding yeast (for review, see Hochstrasser 1998).

We also found that phospho-IкB $\alpha$ destruction motif peptides (but not the nonphosphorylatable counterparts) were able to deplete ubiquitin ligase activity from both 
a

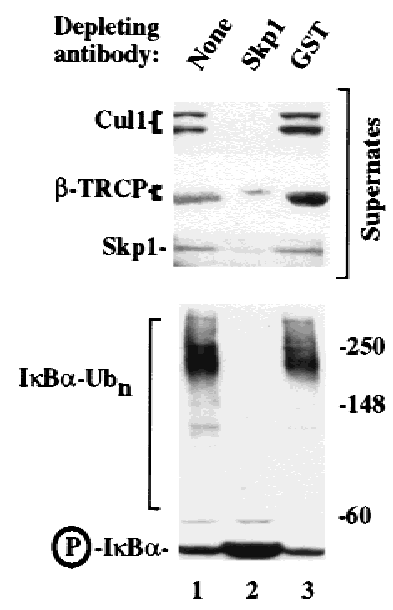

b

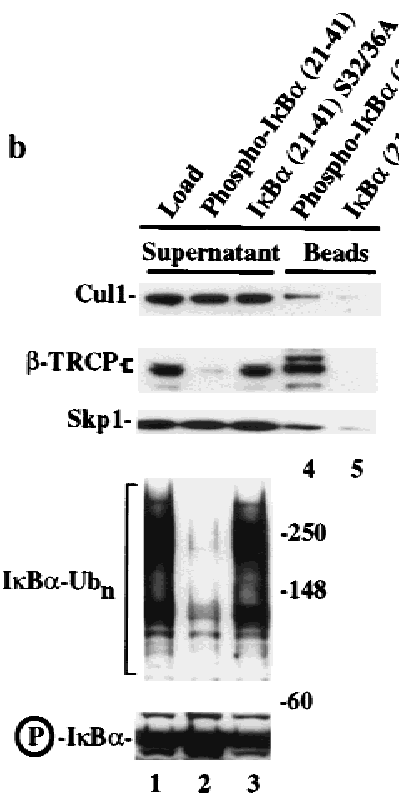

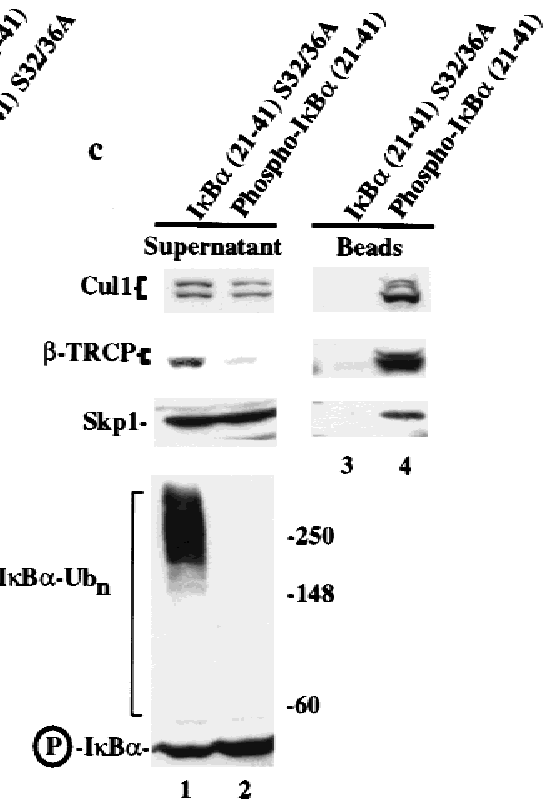

Figure 5. Depletion of IкB $\alpha$-ubiquitin ligase activity by anti-Skp1 antibodies and destruction motif peptides correlates with removal of $\beta$-TRCP. (a) Ubiquitin ligase activity from phenyl-Sepharose fractions 7 and 8 was depleted with antibodies against Skp1 or GST and the supernatant assayed for ubiquitination activity toward phosphorylated IкB (bottom). The levels of Skp1, Cul1, and $\beta$-TRCP in the supernatants from the depleted fractions were determined by immunoblotting $(t o p)$. $(b, c)$ Endogenous $\beta$-TRCP associates with phosphorylated ІкB $\alpha$ destruction motif peptides during depletion of IкB $\alpha$-ubiquitin ligase activity. Crude cell extracts $(b)$ or active fractions from a phenyl-Sepharose column $(c)$ were incubated with beads containing either phosphorylated or nonphosphorylatable Iк $\mathrm{B} \alpha$ peptides and the supernatants assayed for ubiquitin ligase activity (bottom panels). The levels of Skp1, Cul1, and $\beta$-TRCP in the supernatant and associated with destruction motif peptides were determined by immunoblotting (top). $\beta$-TRCP is associated with the phosphorylated destruction motif peptides and is substantially depleted from active ubiquitin ligase fractions.

active fractions from the phenyl-Sepharose column (Fig. 5b) and crude cell extracts (Fig. 5c). Skp1, Cul1, and $\beta$-TRCP were all associated with the phosphorylated destruction motif beads but not with the nonphosphorylatable destruction motif (Fig. 5, b, lanes 4 and 5, and c, lanes 3 and 4). Although the levels of Skp1 and Cull in supernatants were essentially unaffected (Fig. 5, b, lanes $1-3$, and c, lanes 1 and 2), the level of $\beta$-TRCP in the supernatant from both crude and purified fractions was substantially reduced $(\sim 80 \%$ for the crude lysate and $>90 \%$ for the phenyl-Sepharose fraction) (Fig. 5b,c, lanes $1,2)$. These data are consistent with $\beta$-TRCP-associated Skp1 being a small fraction of the total Skp1/Cull complexes present in the cell (see Fig. 1b). Currently available antibodies against $\beta$-TRCP were unable to immunodeplete $\beta$-TRCP from crude lysates or purified fractions, prohibiting a direct analysis of the effects of removal of $\beta$-TRCP on I $\mathrm{K} B \alpha$-ubiquitin ligase activity. Nevertheless, the finding that depletion of $\mathrm{SCF}^{\beta-T R C P}$ from either crude lysates or purified fraction correlates with loss of ubiquitin ligase activity strongly implicates this SCF complex as being involved in I $\kappa \mathrm{B} \alpha$ ubiquitination.

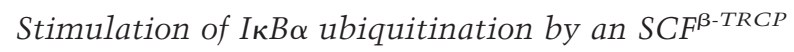 complex in vitro}

The results described thus far are consistent with a role for $\mathrm{SCF}^{\beta \text {-TRCP }}$ in IKB $\alpha$ ubiquitination. If $\beta$-TRCP func- tions as a specificity factor for ubiquitination of IкB $\alpha$ through an SCF-dependent pathway, it should be possible to confer I $\mathrm{B} \alpha$ ubiquitination activity by introducing $\beta$-TRCP into a system that lacks such an activity. Although budding yeast contains a number of E2 enzymes that could potentially support IкB $\alpha$ ubiquitination, its closest homolog to $\beta$-TRCP, Met30, does not associate with the IкB $\alpha$ destruction motif (Fig. 1c). We therefore anticipated that yeast extracts shown previously to support SCF-dependent ubiquitination of $C \ln 2$ and Sic1 (Deshaies et al. 1995; Skowyra et al. 1997; Verma et al. 1997) would be inactive toward either phosphorylated or unphosphorylated IкB $\alpha$ and this was the case (Fig. 6c, lanes 4,5). However, when these same reaction mixtures were supplemented with Flag-tagged SCF $^{\beta-T R C P}$ complexes isolated from $293 \mathrm{~T}$ cells (Fig. 6a), Iк $\mathrm{B} \alpha$ ubiquitination was observed (Fig. 6c, lane 7). The activity was dependent upon phosphorylation of ІкB $\alpha$ (lane 6) and was absent in reaction mixtures containing anti-Flag immunoprecipitates from mock-transfected cells (lanes 8,9). Moreover, SCF $^{\beta-T R C P}$ was unable to stimulate ubiquitination when mixed with E1, ATP, and ubiquitin in the absence of yeast extract (lane 10), indicating that a specific E2 activity is not efficiently immunoprecipitated with the $\mathrm{SCF}^{\beta-\mathrm{TRCP}}$ complex. As expected, the active $S C F^{\beta-T R C P}$ complexes associated with phosphorylated IкB $\alpha$ while control immune complex did not (Fig. 6b). 
a

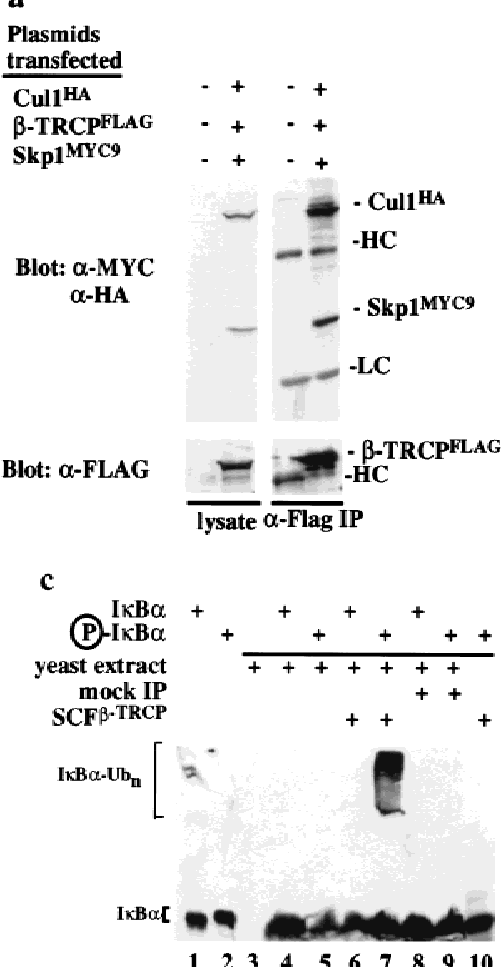

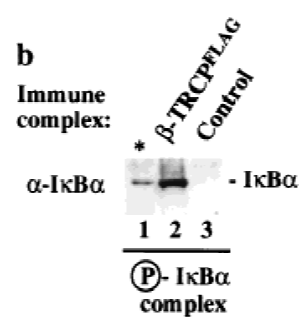

d

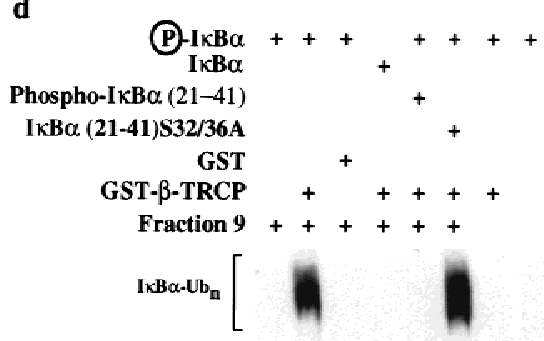

Figure 6. Stimulation of $\operatorname{I\kappa } B \alpha$-ubiquitin ligase activity by $\mathrm{SCF}^{\beta-\mathrm{TRCP}}$ in vitro. $(a)$ Flag-tagged $\mathrm{SCF}^{\beta \text {-TRCP }}$ was prepared after transient transfection in $293 \mathrm{~T}$ cells by immunoprecipitation along with a Flag immune complex from mock-transfected cells. Immune complexes were analyzed for the presence of $\mathrm{Cull}^{\mathrm{HA}}, \mathrm{Skp1}^{\mathrm{Myc}}$, and $\beta$-TRCP $P^{\text {Flag }}$ by immunoblotting (lanes 3,4 ). Crude lysates used for immunoprecipitation are shown as controls (lanes 1,2). (b) $\beta$-TRCP ${ }^{\text {Flag }}$ immune complexes associate with phosphorylated IкB $\alpha$ in vitro. Immune complexes (10 $\mu$ l beads) from $(a)$ were incubated with $15 \mathrm{~nm}$ phosphorylated IкB $\alpha /$ NF- $\kappa$ B complexes in a total volume of $100 \mu \mathrm{l}$. Washed beads were subjected to SDS-PAGE and IкB $\alpha$ determined by immunobloting. The asterisk indicates a sample containing $15 \%$ of the input ІкB $\alpha$ complex. (c) Stimulation of IкB $\alpha$-ubiquitin ligase activity by $\mathrm{SCF}^{\beta-\mathrm{TRCP}}$ in vitro.

-148 Yeast extracts (supplemented with E1, ubiquitin, and an ATP-regenerating system) were incubated with unphosphorylated or phosphorylated ІкB $\alpha / \mathrm{NF}-\kappa \mathrm{B}$ complexes $(25 \mathrm{nM})$ in the presence of $10 \mu \mathrm{l}$ of control immune complexes (lanes 8,9 ) or $\beta$-TRCP ${ }^{\text {Flag }}$ immune complexes (lanes 6,7). After 90 min, reaction mixtures were separated by SDS-PAGE and ІкB $\alpha$ detected by immunoblotting with anti-IкB $\alpha$ antibodies. As controls, untreated IкB $\alpha$ complexes (lanes 1,2), supplemented yeast lysates (lane 3), and an SCF ${ }^{\beta-T_{C P}}$ immune complex reaction mixture containing all components except the yeast extract (lane 10) were also included. (d) Reconstitution of IкB $\alpha$ ubiquitination activity in mammalian extracts by addition of purified GST- $\beta$-TRCP. Reaction mixtures, prepared as described in Materials and Methods, contained E1, ubiquitin, ATP, HQ unbound as a source of E2 activity, and other components as indicated (lanes 1-6). Control reactions (lanes 7,8) lacked phenyl-Sepharose fraction 9. After 90 min, products were analyzed by SDS-PAGE and immunoblotting with anti-IкB $\alpha$ antibodies.

In an alternative approach, we tested whether recombinant GST- $\beta$-TRCP, purified to near homogeneity from insect cells (data not shown), could support ubiquitination of $\mathrm{I} \kappa \mathrm{B} \alpha$ in the mammalian ubiquitination system described in Figure 4. As noted above, fraction 9 from the phenyl-Sepharose column contains Cull and Skp1 but lacks detectable $\beta$-TRCP and ІкB $\alpha$ ubiquitination activity (Fig. 6d, lane 1). However, when this fraction was supplemented with GST- $\beta$-TRCP, a potent phosphorylation-dependent IкB $\alpha$-ubiquitin ligase activity was generated (Fig. 6d, lane 2). This activity was not observed when this fraction was supplemented with purified GST protein (Fig. 6d, lane 3). Also, addition of a phosphorylated IкB $\alpha$ destruction motif peptide (but not the unphosphorylated peptide) completely blocked IкB $\alpha$ ubiquitination (Fig. 6d, lanes 5,6). Finally, the activity was not observed when the GST- $\beta$-TRCP protein was incubated in the reaction conditions lacking the phenyl-Sepharose fraction, suggesting a requirement for Cull and Skp1 (Fig. 6d, lane 7). Taken together, these two assay systems provide compelling evidence that $\mathrm{SCF}^{\beta-\mathrm{TRCP}}$ functions as an IкB-ubiquitin ligase.

\section{Discussion}

Activation of NF- $\mathrm{B}$ involves an extensive signal trans- duction pathway that culminates in the destruction of the NF-кB inhibitor I $\mathrm{B} \alpha$. Although the protein kinase pathways that control the timing of NF- $\mathrm{B}$ activation have been defined, the molecules responsible for the actual ubiquitination events have not been elucidated. In this work, we provide biochemical evidence that the WD-40-containing F-box protein, $\beta$-TRCP, functions as a specificity factor in an SCF complex to promote signaldependent ubiquitination of $\operatorname{I\kappa B} \alpha$ (Fig. 7). A role for $\beta$-TRCP in controlling IкB $\alpha$ ubiquitination is supported by the following findings. (1) Destruction of ІкB $\alpha$ is known to require IкK-dependent phosphorylation of residues (Ser-32 and Ser-36) located in a destruction motif. $\beta$-TRCP and its SCF complex associate with this IкB $\alpha$ destruction motif and with the IкB $\alpha / N F-\kappa B$ complex in a manner that is dependent upon phosphorylation of the $\mathrm{I} \kappa \mathrm{B} \alpha$ destruction motif. A variety of other F-box proteins, including two other WD-40 containing F-box proteins (Met30 and MD6), failed to associate with either phosphorylated or unphosphorylated ІкB $\alpha$ destruction motifs, pointing to the specificity of the interaction with $\beta$-TRCP. We believe that the interaction between $\beta$-TRCP and the IкB $\alpha$ destruction motif is direct, as peptide beads containing this motif precipitate GST- $\beta$ TRCP from insect cell lysates in the absence of other abundant proteins (J. Winston, S. Elledge, and J. Harper, 
Figure 7. Schematic representation of the proposed pathways controlling ubiquitinmediated proteolysis of $\mathrm{I} \kappa \mathrm{B} \alpha$ and $\beta$ catenin. $\beta$-TRCP, an F-box protein, is a component of an SCF-ubiquitin ligase. In response to appropriate signals (i.e., $\mathrm{TNF} \alpha)$, the IкK complex is activated and phosphorylates $\mathrm{I}_{\kappa} \mathrm{B} \alpha$ in complexes with NF-кB on Ser-32 and Ser-36. This complex is then recognized by $\beta$-TRCP in an SCF complex, facilitating ubiquitination by an E1- and E2-dependent mechanism. $\beta$ Catenin, in complexes with APC, axin, and GSK3 $\beta$, is phosphorylated on Ser-33 and Ser-37. This phosphorylated $\beta$-catenin can then associate with $S \mathrm{~F}^{\beta-T R C P}$, resulting in ubiquitination. It is not clear at present whether $\beta$-catenin alone or the APC/ $\beta$-catenin complex is the relevant target. Yellow ovals indicate phosphorylation.

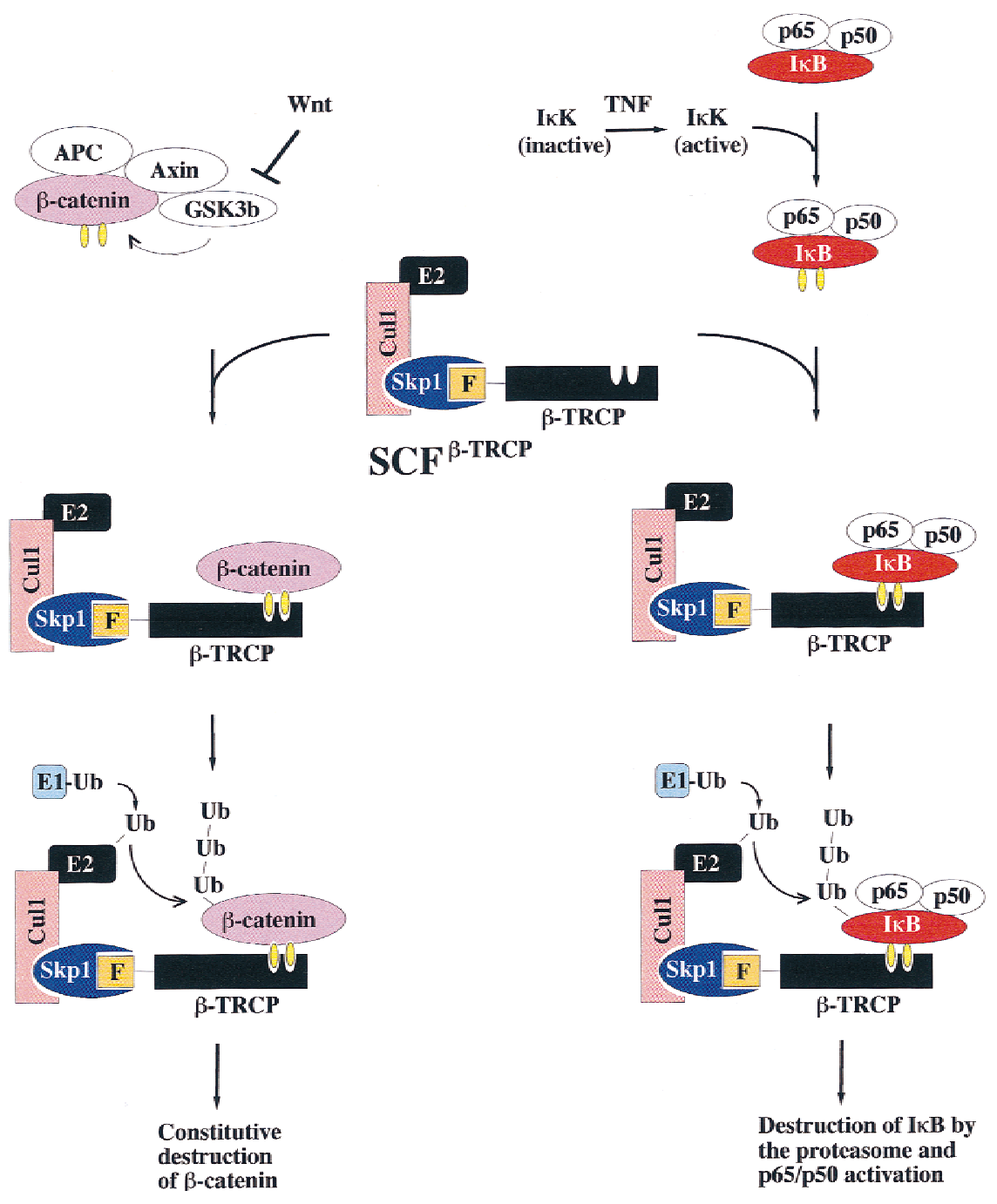

unpubl.). (2) $\beta$-TRCP forms a complex with two proteins, Skp1 and Cul1, that have been linked previously to phosphorylation-dependent ubiquitination. $\beta$-TRCP is localized in the cytoplasm where $I_{\kappa} \mathrm{B} \alpha$ ubiquitination is thought to occur. (3) $\beta$-TRCP copurifies with IкB $\alpha$-ubiquitin ligase activity from tissue culture cells, and these active fractions also contain Cul1 and Skp1. (4) Depletion of $\beta$-TRCP with either anti-Skp1 antibodies or phosphorylated destruction motif peptides correlates with loss of IкB $\alpha$-ubiquitin ligase activity. (5) SCF ${ }^{\beta-T R C P}$ complexes stimulated phosphorylation-dependent ІкВ $\alpha-$ ubiquitin ligase activity when supplemented with E1, ubiquitin, ATP, and a yeast extract. These yeast extracts lack IкB $\alpha$-ubiquitin ligase despite the presence of multiple SCF complexes (Bai et al. 1996; Patton et al. $1998 \mathrm{a}, \mathrm{b})$, providing further evidence of a role for $\beta$-TRCP as a specificity factor for $\mathrm{I} \kappa \mathrm{B} \alpha$, but provide $\mathrm{E} 2$ activities and possibly other components that support IкB $\alpha$ ubiquitination by the $\beta$-TRCP complex. (6) Addition of $\beta$-TRCP to fractions containing Cull and Skp1 but lacking IкB $\alpha$-ubiquitination activity leads to robust ubiquitination activity that is phosphorylation dependent and inhibited by a phosphorylated IкB $\alpha$ destruction motif peptide. At present, we have been unable to reconstitute I $\mathrm{B} \alpha$-ubiquitin ligase activity using $\mathrm{SCF}^{\beta-\mathrm{TRCP}}$ complexes isolated from transfected cells and column fractions depleted of $\beta$-TRCP by either anti-Skp1 antibodies or phospho-ІкB $\alpha$ peptides. This may reflect removal of an essential factor by depletion that is not present in sufficient levels in the transiently expressed SCF complex to support IкB $\alpha$ ubiquitination but are provided in trans by yeast extracts or undepleted mammalian extracts. Taken together, these data provide strong evidence that $\mathrm{SCF}^{\beta-}$ TRCP functions in IкB $\alpha$ ubiquitination. After submission of this paper, Yaron et al. (1998) reported that $\beta$-TRCP is a component of the I $\mathrm{\kappa} B \alpha$-ubiquitin ligase and demonstrated that mutants lacking the F-box stabilize IкB $\alpha$ and block NF- $\mathrm{B}$ activation in vivo. However, no data linking $\beta$-TRCP to an SCF-dependent process was presented, and it was suggested that $\beta$-TRCP might function independently of Cull and Skp1. Our data provide compelling and complementary biochemical evidence that $\beta$-TRCP functions in the context of an SCF pathway, a result that has important mechanistic implications and 
further implicates the SCF pathway in phosphorylationdependent ubiquitination reactions. Currently, the identity of the $\mathrm{E} 2(\mathrm{~s})$ involved in IкB $\mathrm{B}$ ubiquitination in vivo is unknown, as is the nature of the heterogeneity observed with $\beta$-TRCP. We note, however, that other F-box proteins including Skp2 are modified by phosphorylation (Lisztwan et al. 1998), and such modifications could potentially play regulatory roles. The methods we have employed offer two general approaches for determining whether a particular ubiquitination process involves an SCF complex: (1) Depletion of active fractions with Skp1 antibodies, and (2) the use of substrates as affinity reagents to examine association with cloned F-box proteins. The expanding number of F-box protein sequences available will greatly facilitate the identification of SCFdependent processes through these types of approaches.

The sequence conservation of the IкB $\alpha$ destruction motif with a region of $\beta$-catenin implicated in its turnover, coupled with a genetic requirement for the $\beta$-TRCP homolog slimb in turnover of the $\beta$-catenin homolog Armadillo (Jiang and Struhl 1998), led us to address whether $\beta$-TRCP might interact directly with $\beta$-catenin. Phosphorylation of serine residues 33 and 37 was sufficient to allow for a peptide spanning this region to associate with $\beta$-TRCP and its SCF complex but not other F-box proteins. $\beta$-Catenin is a component of the Wingless/Wnt signaling pathway and functions with Tcf/Lef transcription factors to regulate patterning and other developmental decisions (Peifer 1997). Recent work has revealed that expression of a $\beta$-TRCP protein lacking the F-box leads to accumulation of $\beta$-catenin and ectopic activation of the Wnt pathway in Xenopus (Marikawa and Elinson 1998) and $\beta$-catenin stabilization in mammalian cells (Latres et al. 1999). This, together with our data linking $\beta$-TRCP to direct recognition of the phosphorylated $\beta$-catenin destruction motif, strongly implicates $\mathrm{SCF}^{\beta-\mathrm{TRCP}}$ as the $\beta$-catenin-ubiquitin ligase (Fig. 7). The levels of $\beta$-catenin are regulated by the APC (adenomatous polyposis coli) tumor suppressor protein, axin, and the protein kinase GSK3 $\beta$ (Korinek et al. 1997; Morin et al. 1997; Rubinfeld et al. 1997). Formation of an APC/ axin/GSK3 $\beta / \beta$-catenin complex is thought to be required to allow appropriate phosphorylation of $\beta$-catenin by GSK3 $\beta$ (Hart et al. 1998; Ikeda et al. 1998) and in the absence of Wnt signaling, $\beta$-catenin levels remain low due to constitutive phosphorylation and ubiquitin-mediated proteolysis. Wnt signaling inactivates GSK3 $\beta$, leading to increased levels of $\beta$-catenin and activation of transcription (Peifer 1997). Mutations in either the APC gene or in $\beta$-catenin allow for $\beta$-catenin accumulation (Morin et al. 1997; Rubinfeld et al. 1997). Such mutations are found in a large fraction of colon cancers (Morin et al. 1997) and have also been observed in melanoma (Rubinfeld et al. 1997), prostate cancer (Voeller et al. 1998), and experimentally induced cancers (Dashwood et al. 1998). Interestingly, stabilizing mutations in $\beta$-catenin are localized to its destruction motif and include mutations in both the phosphoacceptor sites S33 and S37 and other residues in the consensus $\beta$-TRCP recognition motif including D32, G34, and I35. Mutations in these resi- dues would be expected to weaken or abolish association of $\beta$-catenin with $\beta$-TRCP, leading to accumulation of $\beta$-catenin.

The role for $\beta$-TRCP in $\beta$-catenin turnover suggests that it might function as a tumor suppressor. We localized the human $\beta$-TRCP gene to $10 \mathrm{q} 24$. This region displays genetic abnormalities in a limited number of prostatic, melanocytic, and neural cancers (Parmiter et al. 1988; Lundgren et al. 1992; Rasheed et al. 1992). However, a preliminary analysis of four colon cancers which are wild-type for $\beta$-catenin and APC failed to reveal mutations in the $\beta$-TRCP protein (Sparks et al. 1998). Given the role for $\beta$-TRCP in IкB $\alpha$ ubiquitination, it is conceivable that mutations that inactivate $\beta$-TRCP are incompatible with transformation because of loss of survival pathways dependent on NF-кB activation (Beg and Baltimore 1996; Van Antwerp et al. 1996; Wang et al. 1996).

Our results indicate that an $\mathrm{SCF}^{\beta-T R C P}$ complex functions in two critical transcriptional control pathways, in one case by inactivating an inhibitor of transcription and in the other case by inhibiting an activator of transcription (Fig. 7). Genetic data in Drosophila suggest that the $\beta$-TRCP homolog slimb may also regulate the Hedgehog pathway (Jiang and Struhl 1998). In slimb mutants, the Ci transcription factor accumulates inappropriately, although the question of whether this regulation is direct remains to be determined. Moreover, other recent studies have revealed that $\beta$-TRCP is coopted by the HIV protein $\mathrm{Vpu}$ to facilitate destruction of the CD4 protein (Margottin et al. 1998). Interestingly, Vpu contains a $\beta$-TRCP recognition motif very similar to that found in $\mathrm{I} \kappa \mathrm{B} \alpha$ and $\beta$-catenin and phosphorylation is required for it to recruit CD4 to $\beta$-TRCP and to bind $\beta$-TRCP in the two-hybrid system. Further studies are required to determine whether any of the many proteins containing the DSG $\phi X S$ motif are also substrates for $\mathrm{SCF}^{\beta-\mathrm{TRCP}}$. In addition, we note that the anti-inflammatory effects of aspirin are mediated through inhibition of ІкK activity (Grilli et al. 1996; Yin et al. 1998), thereby blocking NF$\kappa \mathrm{B}$ activation. Molecules that selectively block recognition of IкB $\alpha$ by $\beta$-TRCP may also constitute an alternative therapeutic target for anti-inflammatory agents.

\section{Materials and methods}

\section{Plasmid and baculovirus construction}

cDNAs encoding mouse and human homologs of Xenopus $\beta$-TRCP, human Skp2, and human MD6 were obtained as expressed sequence tags and the sequences determined by automated DNA sequencing. The sequence of human $\beta$-TRCP was reported previously. The sequence of mouse $\beta$-TRCP was deposited in GenBank (accession no. AF110396). The sources of other novel F-box proteins will be reported elsewhere (J. Winston, D. Koepp, S.J. Elledge, and J.W. Harper, in prep.). Open reading frames were amplified by PCR using Expand high-fidelity polymerase (Boehringer Mannheim) and cloned into the univector derivative pUNI10 as NdeI-SalI fragments. Similarly, human Skp1 was cloned into pUNI10 as NdeI-BamHI fragment. In vitro Cre-recombinase-mediated plasmid fusion (Lui et al. 1998) of univector plasmids with various pHOST recipient plas- 
mids was then used to create plasmids for expression of proteins as amino-terminal Myc3, Flag, or $\mathrm{Ha} 3$ fusion proteins under control of the CMV/T7 promoter, and a GST fusion protein for expression in insect cells. Coding sequences for His $_{6}$-tagged IкB $\alpha$, IкK- $\beta$, p 50, and p 65 were amplified by PCR and baculoviruses generated using the Bac-to-Bac system (Invitrogen). Plasmids for expression of Cul1 ${ }^{\mathrm{HA}}$ (Lisztwan et al. 1998) and cyclin F (Bai et al. 1996) were from previous studies. GST fusion proteins were purified from insect cells and eluted from glutathione-Sepharose beads as described previously (Skowyra et al. 1997).

\section{Antibodies}

Polyclonal antibodies against human Skp1 and Cul1 were generated in rabbits after injection of GST-Skp1 or GST-Cul1(536815) produced in bacteria. Antisera were depleted of anti-GST reactivity using immobilized bacterial GST protein and then affinity purified using immobilized GST-Skp1 or GSTCull(536-815). Antibodies against the carboxyl terminus of $\beta$-TRCP were generated in rabbits using the peptide NETRSPSRTYTYISR. Antibodies were affinity purified using this peptide coupled to Affigel-10 (Bio-Rad). Monoclonal antibodies recognizing $\mathrm{Myc}, \mathrm{Ha}$, or Flag epitopes were obtained from BabCO or Sigma. Antibodies against the phosphorylated Iк $\mathrm{B} \alpha$ destruction motif were from New England Biolabs. All other antibodies were from Santa Cruz Biotechnology.

\section{In vitro binding}

Twenty-one (p21, residues 21-42) and 19 (p19, residues 23-41) amino acid peptides containing the I $\mathrm{B} \alpha$ destruction motif were synthesized in both the unphosphorylated and doubly phosphorylated forms where serines 32 and 36 are phosphorylated as described previously (Yaron et al. 1997). Analogous unphosphorylated and doubly phosphorylated peptides overlapping a candidate destruction motif in $\beta$-catenin were also synthesized. p21 and $\beta$-catenin peptides were coupled to Affigel (Bio-Rad) at $2 \mathrm{mg} / \mathrm{ml}$ of resin and $\mathrm{p} 19$ peptides were coupled to cyanogen bromide activated Sepharose (Pharmacia) at $10 \mathrm{mg} / \mathrm{ml}$ resin. Coupling efficiencies were determined to be $>90 \%$ by analytical reverse-phase HPLC of reaction supernatants. To examine association of Skpl containing complexes with destruction motifs, binding reactions were performed in a total volume of 120 $\mu \mathrm{l}$ of $20 \mathrm{~mm}$ Tris- $\mathrm{HCl}$ (pH 7.5), $150 \mathrm{~mm} \mathrm{NaCl}, 0.35 \%$ NP-40, 1 mM DTT, $0.75 \mathrm{~mm}$ EDTA, and $5 \mu \mathrm{g} / \mathrm{ml}$ antipain, leupeptin, and aprotinin using $15 \mu \mathrm{l}$ of peptide beads and the indicated quantity of cell lysate or column fraction. After incubation at $4^{\circ} \mathrm{C}$ for $\sim 1$ $\mathrm{hr}$, beads were washed three times with $1 \mathrm{ml}$ of binding buffer [20 mM Tris- $\mathrm{HCl}(\mathrm{pH} 7.5), 150 \mathrm{~mm} \mathrm{NaCl}, 0.5 \% \mathrm{NP}-40,1 \mathrm{~mm}$ DTT, $1 \mathrm{~mm}$ EDTA, and $5 \mu \mathrm{g} / \mathrm{ml}$ antipain, leupeptin, and aprotinin] prior to SDS-PAGE $(13.5 \%)$ and immunoblotting using the indicated antibodies. Antibody detection was accomplished using ECL (Amersham). To examine association of F-box proteins with peptide beads, $\left[{ }^{35} \mathrm{~S}\right]$-methionine-labeled in vitro translation products of various F-box proteins were employed. Comparable quantities of translation products (typically 5-10 $\mu \mathrm{l})$ were diluted to $120 \mu \mathrm{l}$ with binding buffer prior to incubation with $15 \mu \mathrm{l}$ of peptide beads $\left(4^{\circ} \mathrm{C}, 1 \mathrm{hr}\right)$. Beads were washed three times with binding buffer prior to electrophoresis and autoradiography.

\section{In vivo interactions}

To examine assembly of $\mathrm{SCF}^{\beta-\mathrm{TRCP}}$ complexes in mammalian cells, 293T cells were transfected with various combinations of plasmids ( $1 \mu \mathrm{g}$ each/10-cm dish) expressing Myc, Flag, or Hatagged Skp1, $\beta$-TRCP (mouse), and Cull under control of the CMV promoter using lipofectamine (GIBCO/BRL). The total DNA level was kept constant at $10 \mu \mathrm{g}$ using empty vector DNA and each transfection contained $100 \mathrm{ng}$ of pCMV-GFP DNA to facilitate determination of transfection efficiency (typically $>90 \%$ ). Forty hours post-transfection, cells were lysed in binding buffer supplemented with $10 \mathrm{~mm} \beta$-glycerol phosphate, 5 $\mathrm{mm} \mathrm{NaF}$, and $1 \mathrm{~mm}$-nitrophenylphosphate (30 $\mathrm{min}$ on ice). After centrifugation $(14,000 \mathrm{rpm}, 20 \mathrm{~min})$, lysates $(1 \mathrm{mg} / 0.5 \mathrm{ml})$ were subjected to immunoprecipitation using $10 \mu \mathrm{l}$ of anti-Myc or anti-HA immobilized on agarose beads, or used in peptide bead binding reactions as described above. Washed immune complexes were separated by SDS-PAGE and immunoblotted using the indicated antibodies. In some experiments, immune complexes from transfected cells were used for ubiquitination reactions (see below) or for binding to IкB $\alpha / \mathrm{NF}-\kappa \mathrm{B}$ complexes. For binding experiments, immobilized SCF complexes from one $10-\mathrm{cm}$ dish of transfected $293 \mathrm{~T}$ cells (10 $\mu \mathrm{l}$ of beads) were incubated with $15 \mathrm{nM} \mathrm{I \kappa B} \alpha / \mathrm{NF}-\kappa \mathrm{B}$ complexes in a total volume of $100 \mu \mathrm{l}$ of binding buffer for $60 \mathrm{~min}$. Beads were washed three times with $600 \mu \mathrm{l}$ of binding buffer prior to immunoblotting for p50 and $\mathrm{I \kappa B} \alpha$.

\section{In vitro ubiquitination}

To generate IкB $\alpha /$ NF- $\kappa \mathrm{B}$ complexes as a substrate for ubiquitination, insect cells were coinfected with viruses expressing $\mathrm{His}_{6}-\mathrm{I} \kappa \mathrm{B} \alpha$, p50, and p 65 and complexes purified on nickel-NTA resin. Proteins were eluted with imidazole and the heterotrimeric complex size-selected by gel filtration. To generate phosphorylated IкB $\alpha$, the IкB $\alpha /$ p50/p65 complex $(3 \mu \mathrm{M})$ was incubated with IкK- $\beta$ (500 nM) purified from insect cells and $300 \mu \mathrm{M}$ ATP, $10 \mathrm{~mm} \mathrm{MgCl}_{2}, 1 \mathrm{~mm}$ DTT, $50 \mathrm{~mm}$ Tris (pH 7.5) for $2 \mathrm{hr}$ at $25^{\circ} \mathrm{C}$. IкB $\alpha$-ubiquitin ligase activity in THP. 1 cell extracts and column fractions was assayed as described previously (Chen et al. 1995) using $25 \mathrm{~nm}$ phosphorylated or unphosphorylated IкB $\alpha /$ NF-кB complexes, HQ unbound ( $33 \mu \mathrm{g})$, and 200 nм E1. Proteins were separated by $4 \%-20 \%$ Novex SDS-PAGE, transferred to nitrocellulose, and ІкB $\alpha$ revealed with anti-IкB $\alpha$ antibodies. THP.1 cell extracts were prepared by Dounce homogenization (10 strokes) in eight volumes (wt/vol) of buffer containing $50 \mathrm{~mm}$ Tris, $1 \mathrm{~mm}$ DTT, $1 \mathrm{~mm}$ EDTA, $1 \mathrm{~mm}$ EGTA, $1 \times$ Boehringer Mannheim protease inhibitor cocktail (EDTA-free) and centrifuged at 25,000 $\mathrm{g}$ for $25 \mathrm{~min}$. The filtered supernatant was fractionated on a POROS HQ column equilibrated in dialysis buffer lacking glycerol to obtain unbound fraction (HQ unbound) or precipitated with ammonium sulfate. The 30\%-50\% ammonium sulfate cut equivalent to 1 gram of cell paste was solubilized in $3 \mathrm{ml}$ of dialysis buffer $(25 \mathrm{~mm}$ Tris at $\mathrm{pH} 7.5,10 \%$ glycerol, $1 \mathrm{~mm}$ DTT, $1 \mathrm{~mm}$ Benzamidine, $0.4 \mathrm{~mm}$ PMSF). The solubilized pellet $(2 \mathrm{ml})$ was adjusted to $1.2 \mathrm{M}$ ammonium sulfate, loaded to phenyl-Sepharose column (Pharmacia 5/5) equilibrated in dialysis buffer containing $1.2 \mathrm{M}$ ammonium sulfate but without glycerol, and bound proteins eluted with a 20 column volume gradient $1.2-0 \mathrm{M}$ ammonium sulfate, collecting two-column volume fractions followed by dialysis. To deplete IкB $\alpha$-ubiquitin ligase activity from crude extracts $(5 \mathrm{mg} / \mathrm{ml})$ or phenyl-Sepharose fractions $(0.7 \mathrm{mg} / \mathrm{ml})$, p19 or pp19 beads $(5 \mu \mathrm{l})$ were incubated with $30 \mu \mathrm{l}$ of sample for $2 \mathrm{hr}$. Unbound material was removed for ubiquitination assays or immunoblotting and proteins associated with washed beads were subjected to SDSPAGE and immunoblotting. Skp1 was immunodepleted by precoupling $30 \mu \mathrm{l}$ of protein $\mathrm{G}$ beads (Pierce) with $1 \mathrm{ml}$ of anti-Skp1 
or anti-GST mouse monoclonal $\mathrm{IgG}_{1}$ antibodies (Transduction Laboratories) at $45 \mu \mathrm{g} / \mathrm{ml}$ for $2 \mathrm{hr}$. Washed beads were incubated with phenyl-Sepharose pools for $3 \mathrm{hr}$ as indicated above.

To assay I $\mathrm{B} B \alpha$ ubiquitination activity in yeast extracts, $50 \mu \mathrm{g}$ of crude yeast extract (Deshaies et al. 1995) was supplemented with $100 \mathrm{ng}$ of human E1, $200 \mu \mathrm{g}$ of ubiquitin, $2 \mathrm{~mm}$ ATP (together with an ATP regenerating system), $10 \mu \mathrm{M}$ LLNL, and 25 $\mathrm{nM}$ of $\mathrm{I} \kappa \mathrm{B} \alpha / \mathrm{NF}-\kappa \mathrm{B}$ complexes as substrate in a total volume of $10 \mu \mathrm{l}\left(50 \mathrm{~mm}\right.$ Tris- $\mathrm{HCl}$ at $\left.\mathrm{pH} 7.5,5 \mathrm{~mm} \mathrm{MgCl}_{2}, 0.6 \mathrm{~mm} \mathrm{DTT}\right)$. Reaction mixtures were incubated with SCF immune complexes or control immune complexes from transfected 293T cells (10 $\mu$ l of beads per assay) for $90 \mathrm{~min}$ at $30^{\circ} \mathrm{C}$ and products analyzed by SDS-PAGE and immunoblotting with antibodies against IкB $\alpha$. We estimate that the reaction mixture contained $50-100 \mathrm{ng}$ of SCF complexes. To assay ІкВ $\alpha$ ubiquitination activity in reconstituted mammalian extracts, GST- $\beta$-TRCP or GST proteins purified from insect cells (200 ng) were added to $100 \mu \mathrm{g}$ of phenyl-Sepharose fraction 9 followed by HQ unbound $(33 \mu \mathrm{g})$, E1 (200 ng), ubiquitin $(5 \mu \mathrm{M})$, and ATP ( $2 \mathrm{mM})$ in a final volume of $15 \mu \mathrm{l}(90 \mathrm{~min})$. In some cases, ІкB $\alpha$ peptides were added at $50 \mu \mathrm{g} / \mathrm{ml}$.

\section{Chromosomal localization and in situ hybridization}

Genomic clones (Bacmids $171 \mathrm{I}$ a and 350H4) that hybridize to the human $\beta$-TRCP cDNA were obtained from Research Genetics. The chromosomal localization of the human $\beta$-TRCP gene was determined by fluorescence in situ hybridization by the Baylor College of Medicine FISH facility. RNA expression analysis by in situ hybridization was performed as described (Parker et al. 1995) using antisense mouse $\beta$-TRCP sequences as a probe and sense sequences as a negative control (data not shown).

\section{Acknowledgments}

We are extremely grateful to Mark Rolfe at Mitotix for his efforts in coordinating this work. We thank W. Krek for a Cull expression plasmid; C. Wong for in situ hybridization; D. Koepp for F-box protein expression constructs; S. Glass for molecular biology; I. Chiu and A. Frederick for p50 cloning; M. Pelletier for IкK reaction optimization; and $\mathrm{M}$. Caligiuri, A. Theodoras, L. Brizuela, G. Draetta, R. Copeland, K. Auger, K. Wee, and D. Skowyra for insightful discussions. This work is supported by grants from the National Institutes of Health [National Institute on Aging (NIA)], the Welch Foundation, and the Baylor Specialized Program of Research Excellence in Prostate Cancer to J.W.H and S.J.E.; and by the Dupont Pharmaceutical Company to Mitotix, Inc. J.W. is supported by a postdoctoral training grant from NIA. S.J.E. is an Investigator with the Howard Hughes Medical Institute.

The publication costs of this article were defrayed in part by payment of page charges. This article must therefore be hereby marked 'advertisement' in accordance with 18 USC section 1734 solely to indicate this fact.

\section{References}

Aberle, H., A. Bauer, J. Stappert, A. Kispert, and R. Kemler. 1997. $\beta$-Catenin is a target for the ubiquitin-proteasome pathway. EMBO J. 16: 3797-3804.

Alkalay, I., A. Yaron, A. Hatzubai, A. Orian, A. Ciechanover, and Y. Ben-Neriah. 1995. Stimulation-dependent I kappa B alpha phosphorylation marks the NF-kappa B inhibitor for degradation via the ubiquitin-proteasome pathway. Proc. Nat1. Acad. Sci. 92: 10599-10603.

Bai, C., P. Sen, N. Mathias, K. Hofmann, M. Goebl, J.W. Harper, and S.J. Elledge. 1996. SKP1 connects cell cycle regulation to the ubiquitin proteolysis machinery through a novel motif, the F-box. Cell 86: 263-274.

Baeuerle, P.A. and D. Baltimore. 1996. NF-кB: Ten years after. Cell 87: 13-20.

Beg, A.A. and D. Baltimore. 1996. An essential role for NF-кB in preventing TNF $\alpha$-induced cell death. Science 274: 782-784.

Beg, A.A., S.M. Ruben, R.I. Scheinman, S. Haskill, C.A. Rosen, and A.S. Baldwin, Jr. 1992. ІкB interacts with the nuclear localization sequences of the subunits of NF-кB: A mechanism for cytoplasmic retention. Genes \& Dev. 6: 1899-1913.

Beg, A.A., T.S. Finco, P.V. Nantermet, and A.S.J. Baldwin. 1993. Tumor necrosis factor and interleukin-1 lead to phosphorylation and loss of ІкB $\alpha$ : A mechanism for NF-кB activation. Mol. Cell. Biol. 13: 3301-3310.

Brown, K., S. Gerstberger, L. Carlson, G. Fransozo, and U. Siebenlist. 1995. Control of IкB $\alpha$ proteolysis by site-specific, signal-induced phosphorylation. Science 267: 1485-1488.

Chen, Z., J. Hagler, V.J. Palombella, F. Melandri, D. Scherer, D. Ballard, and T. Maniatis. 1995. Signal-induced site-specific phosphorylation targets Iк $\mathrm{B} \alpha$ to the ubiquitin-proteasome pathway. Genes \& Dev. 9: 1586-1597.

Chen, Z.J., L. Parent, and T. Maniatis. 1996. Site-specific phosphorylation of $\mathrm{I} \kappa \mathrm{B} \alpha$ by a novel ubiquitination-dependent protein kinase activity. Cell 84: 853-862.

Cohen, L., J.W. Henzel, and P.A. Baeuerle. 1998. IKAP is a scaffold protein of the IkappaB kinase complex. Nature 395: 292-296.

Dashwood, R.H., M. Suzui, H. Nakagam, T. Sugimura, and M. Nagao. 1998. High frequency of $\beta$-catenin (Ctnnb1) mutations in the colon tumors induced by two heterocyclic amines in the F344 rat. Cancer Res. 58: 1127-1129.

Deshaies, R.J., V. Chau, and M. Kirschner. 1995. Ubiquitination of the G1 cyclin $C \ln 2 p$ by a Cdc34p-dependent pathway. EMBO J. 14: 303-312.

DiDonato, J.A., F. Mercurio, and M. Karin. 1995. Phosphorylation of IкB $\alpha$ precedes but is not sufficient for its dissociation from NF-кB. Mol. Cell. Biol. 15: 1302-1311.

DiDonato, J.A., M. Hayakawa, D.M. Rothwarf, E. Zandi, and M. Karin. 1997. A cytokine-responsive IкB kinase that activates the transcription factor NF-кB. Nature 388: 548-554.

Elledge, J.W. and J.W. Harper. 1998. Proteolysis in cell cycle control and cancer. Biochem. Biophys. Acta 1377: M61M70.

Feldman, R.M., C.C. Correll, K.B. Kaplan, and R.J. Deshaies. 1997. A complex of Cdc4p, Skplp, and Cdc53p/cullin catalyzes ubiquitination of the phosphorylated CDK inhibitor Siclp. Cell 91: 221-230.

Finco, T.S., A.A. Beg, and A.S.J. Baldwin. 1994. Inducible phosphorylation of IкB $\alpha$ is not sufficient for its dissociation from NF-кB and is inhibited by protease inhibitors. Proc. Nat1. Acad. Sci. 91: 11884-11888.

Gilmore, T.D., M. Koedood, K.A. Piffat, and D.W. White. 1996. Rel/NF-кB/IкB proteins and cancer. Oncogene 13: 13671378.

Grilli, M., M. Pizzi, M. Memo, and P. Spano. 1996. Neuroprotection by aspirin and sodium salicylate through blockade of NF-kappa B activation. Science 274: 1383-1385.

Hart, M.J., R. de los Santos, I. Albert, B. Rubinfeld, and P. Polakis. 1998. Downregulation of $\beta$-catenin by human Axin and its assocation with the APC tumor suppressor, $\beta$-catenin and GSK3 $\beta$. Curr. Biol. 8: 573-581.

Hershko, A., H. Heller, S. Elias, and A. Ciechanover. 1983. 
Components of the ubiquitin-protein ligase system. Resolution, affinity purification, and role in protein breakdown. $J$. Biol. Chem. 258: 8206-8214.

Hochstrasser, M. 1995. Ubiquitin, proteasomes, and the regulation of intracellular protein degradation. Curr. Opin. Cell Biol. 7: 215-223.

- 1996. Protein degradation or regulation: Ub the judge. Cell 84: 813-815.

1998. There's the rub: A novel ubiquitin-like modification linked to cell cycle regulation. Genes \& Dev. 12: 901907.

Ikeda, S., S. Kishida, H. Yamamoto, H. Murai, S. Koyama, and A. Kikuchi. 1998. Axin, a negative regulator of the Wnt signaling pathway, forms a complex with GSK- $3 \beta$ and $\beta$-catenin and promotes GSK-3 $\beta$-dependent phosphorylation of $\beta$-catenin. EMBO J. 17: 1371-1384.

Jiang, J. and G. Struhl. 1998. Regulation of the hedgehog and wingless pathways by the F-box/WD40-repeat protein slimb. Nature 391: 493-496.

Korinek, V., N. Barker, P.J. Morin, D. van Wichen, R. de Weger, K.W. Kinzler, B. Vogelstein, and H. Clevers. 1997. Constitutive transcriptional activation by a $\beta$-catenin-Tcf complex in APC-/- colon carcinoma. Nature 275: 1784-1787.

Latres, E., D.S. Chiaur, and M. Pagano. 1999. The human F box protein $\beta$-TRCP associates with the Cull/Skp1 complex and regulates the stability of $\beta$-catenin. Oncogene (in press).

Lin, Y.-C., K. Brown, and U. Siebenlist. 1995. Activation of NF$\kappa B$ requires proteolysis of the inhibitor I $\mathrm{B}-\alpha$ : Signal-induced phosphorylation of ІкB $\alpha$ alone does not release active NF-кB. Proc. Natl. Acad. Sci. 92: 552-556.

Lisztwan, J., A. Marti, H. Sutterluty, M. Gstaiger, C. Wirbelauer, and W. Krek. 1998. Association of human CUL-1 and ubiquitin-conjugating enzyme CDC34 with the F-box protein p45(SKP2): Evidence for evolutionary conservation in the subunit composition of the CDC34-SCF pathway. EMBO J. 17: 368-383.

Liu, Z.-G., H. Hsu, D.V. Goeddel, and M. Karin. 1996. Dissection of TNF receptor 1 effector functions: JNK activation is not linked to apoptosis while NF-кB activation prevents cell death. Cell 87: 565-576.

Liu, Q., M.Z. Li, D. Leibman, D. Cortez, and S.J. Elledge. 1998. The univector plasmid fusion system, a method for rapid construction of recombinant DNA molecules without restriction enzymes. Curr. Biol. 8: 1300-1309.

Lundgren, R., N. Mandahl, S. Heim, J. Limon, H. Henrikson, and F. Mitelman. 1992. Cytogenetic analysis of 57 primary prostatic adenocarcinomas. Genes Chromosomes Cancer 4: $16-24$.

Lyapina, S.A., C.C. Correll, E.T. Kipreos, and R.J. Deshaies. 1998. Human CUL1 forms an evolutionarily conserved ubiquitin ligase complex (SCF) with SKP1 and an F-box protein. Proc. Natl. Acad. Sci. 95: 7451-7456.

Margottin, F., S.P. Bour, H. Durand, L. Selig, S. Benichou, V. Richard, D. Thomas, K. Strebel, and R. Benarous. 1998. A novel human WD40 protein, h- $\beta$ TrCP, that interacts with HIV-1 vpu connects CD4 to the ER degradation pathway through an F-box motif. Mol. Cell 1: 565-574.

Marikawa, Y. and R.P. Elinson. 1998. $\beta$-TRCP is a negative regulator of $\mathrm{Wnt} / \beta$-catenin signaling pathway and dorsal axis formation in Xenopus embryos. Mech. Dev. 77: 75-80.

Mercurio, F., H. Zhu, B.W. Murray, A. Shevchenko, B.L. Bennett, J. Li, D.B. Young, M. Barbosa, and M. Mann. 1997. IKK-1 and IKK-2: Cytokine-activated IкB kinases essential for NF-кB activation. Science 278: 860-866.

Michel, J.J. and Y. Xiong. 1998. Human CUL-1, but not other cullin family members, selectively interacts with SKP1 to form a complex with SKP2 and cyclin A. Cell Growth Differ. 9: 435-449.

Morin, P.J., A.B. Sparks, V. Korinek, N. Barker, H. Clevers, B. Vogelstein, and K.W. Kinzler. 1997. Activation of $\beta$-cateninTcf signaling in colon cancer by mutations in $\beta$-catenin or APC. Nature 275: 1787-1790.

Parmiter, A.H., G. Balaban, W.H. Clark, Jr., and P.C. Nowell. 1988. Possible involvement of the chromosome region 10q24-q26 in early stages of melanocytic neoplasia. Cancer Genet. Cytogenet. 30: 313-317.

Patton, E.E., A.R. Willems, D. Sa, L. Kuras, D. Thomas, K.L. Craig, and M. Tyers. 1998a. Cdc53 is a scaffold protein for multiple Cdc34/Skp1/F-box protein complexes that regulate cell division and methionine biosynthesis in yeast. Genes \& Dev. 12: 692-705.

Patton, E.E., A.R. Willems, and M. Tyers. 1998b. Combinatorial control in ubiquitin-dependent proteolysis: Don't Skp the F-box hypothesis. Trends Genet. 14: 236-243.

Parker, S.B., G. Eichele, P. Zhang, A. Rawls, A.T. Sands, A. Bradley, E.N. Olson, J.W. Harper, and S.J. Elledge. 1995. p53independent expression of p21Cip1 in muscle and other terminally differentiating cells. Science 267: 1024-1027.

Peifer, M. 1997. $\beta$-Catenin as oncogene: The smoking gun. Science 275: 1752-1753.

Rasheed, B.K., G.N. Fuller, A.H. Friedman, D.D. Bigner, and S.H. Bigner. 1992. Loss of heterozygosity for 10q loci in human gliomas. Genes Chromosomes Cancer 5: 75-82.

Regnier, C.H., H.Y. Song, X. Gao, D.V. Goeddel, Z. Cao, and M. Rothe. 1997. Identification and characterization of an IкB kinase. Cell 90: 373-383.

Rolfe, M., P. Beer-Romero, S. Glass, J. Eckstein, I. Berdo, A. Theodoras, M. Pagano, and G. Draetta. 1995. Reconstitution of p53-ubiquitination reactions from purified components: The role of human ubiquitin-conjugating enzyme UBC4 and E6-associated protein (E6AP). Proc. Natl. Acad. Sci. 92: 3264-3268.

Rothwarf, D.M., E. Zandi, G. Natoli, and M. Karin. 1998. IKKgamma is an essential regulatory subunit of the IkappaB kinase complex. Nature 395: 297-300.

Rubinfeld, B., P. Robbins, M. El-Gamil, I. Albert, E. Porfiri, and P. Polakis. 1997. Stabilization of $\beta$-catenin by genetic defects in melanoma cell lines. Science 275: 1790-1793.

Scheffner, M., U. Nuber, and J.M. Huibregtse. 1995. Protein ubiquitination involving an E1-E2-E3 enzyme ubiquitin thioester cascade. Nature 373: 81-83.

Scherer, D.C., J.A. Brockman, Z. Chen, T. Maniatis, and D.W. Ballard. 1995. Signal-induced degradation of IкB $\alpha$ requires site-specific ubiquitination. Proc. Natl. Acad. Sci. 92: 11259-11263.

Skowyra, D., K. Craig, M. Tyers, S.J. Elledge, and J.W. Harper. 1997. F-box proteins are components of E3 complexes and act as receptors to recruit phosphorylated substrates for ubiquitination. Cell 91: 209-219.

Sparks, A.B., B. Vogelstein, and K. Kinzler. 1998. No mutations of the slimb homolog, beta-TRCP, in colorectal cancer. Neg. Obser. Gen. Oncol. 2: 23.

Spevak, W., B.D. Keiper, C. Stratowa, and M.J. Castanon. 1993. Saccharomyces cerevisiae cdc15 mutants arrested in a late stage in anaphase are rescued by Xenopus cDNAs encoding $\mathrm{N}$-ras or a protein with beta-transducin repeats. Mol. Cell. Biol. 13: 4953-4966.

Van Antwerp, D.J., S.J. Martin, T. Kafri, D.R. Green, and I.M. Verma. 1996. Suppression of TNF $\alpha$-induced apoptosis by NF-кB. Science 274: 787-789.

Verma, R., R.M. Feldman, and R.J. Deshaies. 1997. SIC1 is ubiquitinated in vitro by a pathway that requires CDC4, CDC34, 
and cyclin/CDK activities. Mol. Biol. Cell 8: 1427-1437.

Voeller, H.J., C.I. Truica, and E.P. Gelmann. 1998. $\beta$-Catenin mutations in human prostate cancer. Cancer Res. 58: 2520 2523.

Wang, C.-Y., M.W. Mayo, and A.S. Baldwin, Jr. 1996. TNF- and cancer therapy-induced apoptosis: Potentiation by inhibition of NF-кB. Science 274: 784-787.

Woronicz, J.D., X. Gao, Z. Cao, M. Rothe, and D.V. Goeddel. 1997. ІкB kinase- $\beta$ : NF-кB activation and complex formation with IкB kinase- $\alpha$ and NIK. Science 278: 866-869.

Wulczyn, F.G., D. Krappmann, and C. Scheidereit. 1998. Signaldependent degradation of IkappaBalpha is mediated by an inducible destruction box that can be transferred to NF-kappaB, bcl-3, or p53. Nucleic Acids Res. 26: 1724-1730.

Yamaoka, S., G. Courtois, C. Bessia, S.T. Whiteside, R. Weil, F. Agou, H.E. Kirk, R.J. Kay, and A. Israel. 1998. Complementation cloning of NEMO, a component of the IкB kinase complex essential for NF-кB activation. Cell 93: 1231-1240.

Yaron, A., H. Gonen, I. Alkalay, A. Hatzubai, S. Jung, S. Beyth, F. Mercurio, A.M. Manning, A. Ciechanover, and Y. BenNeriah. 1997. Inhibition of NF-кB cellular function via specific targeting of the ІкB-ubiquitin ligase. EMBO J. 16: 64866494.

Yaron, A., A. Hatzubal, M. Davis, I. Lavon, S. Amit, A.M. Manning, J.S. Andersen, M. Mann, F. Mercurio, and Y. Ben-Neriah. 1998. Identification of the receptor component of the IkBa-ubiquitin ligase. Nature 396: 590-594.

Yin, M.J., Y. Yamamoto, and R.B. Gaynor. 1998. The anti-inflammatory agents aspirin and salicylate inhibit the activity of I(kappa)B kinase-beta. Nature 396: 77-80.

Zandi, E., D.M. Rothwarf, M. Delhase, M. Hayakawa, and M. Karin. 1997. The IкB kinase complex (IKK) contains two kinase subunits, IKK $\alpha$ and IKK $\beta$, necessary for IкB phosphorylation and NF-кB activation. Cell 91: 243-252.

Zandi, E., Y. Chen, and M. Karin. 1998. Direct phosphorylation of IkappaB by IKKalpha and IKKbeta: Discrimination between free and NF-kappaB-bound substrate. Science 281: 1360-1363. 


\section{Erratum}

Genes \& Development 13: 270-283 (1999)

The $\mathrm{SCF}^{\beta-T R C P}$-ubiquitin ligase complex associates specifically with phosphorylated destruction motifs in IкB $\alpha$ and $\boldsymbol{\beta}$-catenin and stimulates $\mathrm{I} \kappa \mathrm{B} \boldsymbol{\alpha}$ ubiquitination in vitro

Jefferey T. Winston, Peter Strack, Peggy Beer-Romero, Claire Y. Chu, Stephen J. Elledge, and J. Wade Harper

Figure $3 \mathrm{a}$ of the above article was misprinted. The correct figure appears below with its legend in its entirety.

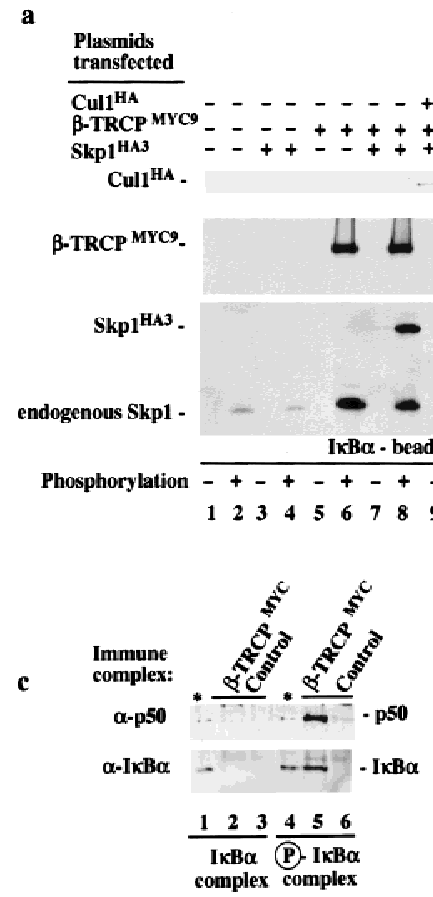

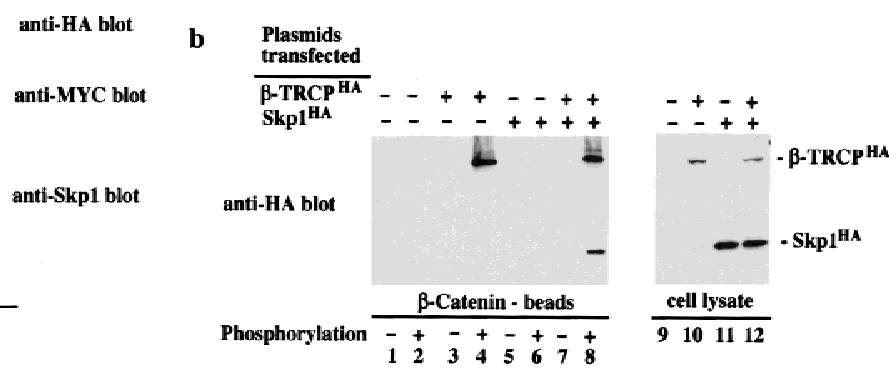

Figure 3. Association of $\mathrm{SCF}^{\beta-\mathrm{TRCP}}$ with $\mathrm{I}_{\kappa} \mathrm{B} \alpha$ and $\beta$-catenin destruction motifs and with the $\mathrm{I}_{\kappa} \mathrm{B} \alpha /$ NF-кB complex. $(a, b)$ Cell lysates $(0.3 \mu \mathrm{g}$ of protein/150 $\mu \mathrm{l})$ from Fig. 2 were used in ІкВ $\alpha(a)$ and $\beta$-catenin $(b)$ peptide bead binding reactions as described in Materials and Methods. Bound proteins were analyzed by immunoblotting with the indicated antibodies. (c) Phosphorylation-dependent association of $\beta$-TRCP ${ }^{\mathrm{Myc}}$ with the IкB $\alpha / \mathrm{p} 50 / \mathrm{p} 65$ complex in vitro. $\beta$-TRCP ${ }^{\mathrm{Myc}}$ immune complexes (lanes 2,5) corresponding to those in Fig. 2a (lane 3) or control complexes (lanes 3,6) corresponding to those in Fig. 2a (lane 1) were used in binding reactions with either ІкB $\alpha / \mathrm{p} 50 / \mathrm{p} 65$ or ІкK- $\beta$ phosphorylated IкB $\alpha / \mathrm{p} 50 / \mathrm{p} 65$ complexes (see Materials and Methods). Bound proteins were separated by SDS-PAGE and immunoblotted using anti-p50 or anti-IкB $\alpha$ antibodies. The asterisk (lanes $1,4)$ indicates the positions of $15 \%$ of the input ІкB $\alpha$ complexes used in the binding reaction. 


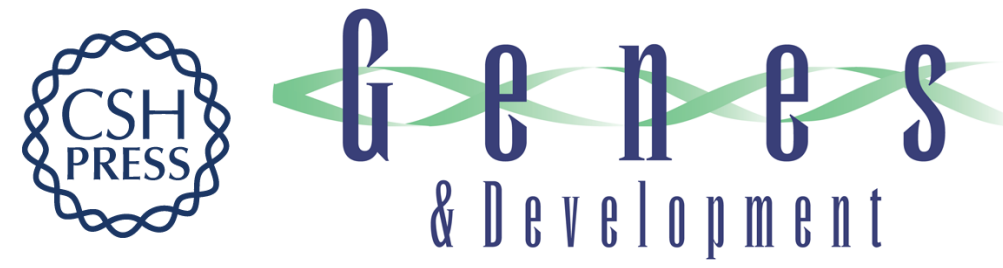

\section{The SCF $\beta$-TRCP -ubiquitin ligase complex associates specifically with phosphorylated destruction motifs in $\mathrm{I} \kappa \mathrm{B} \alpha$ and $\beta$-catenin and stimulates I $\kappa B \alpha$ ubiquitination in vitro}

Jeffrey T. Winston, Peter Strack, Peggy Beer-Romero, et al.

Genes Dev. 1999, 13:

Related Content Errata for vol. 13, p. 270

Genes Dev. April , 1999 13: 1050

References This article cites 65 articles, 33 of which can be accessed free at: http://genesdev.cshlp.org/content/13/3/270.full.html\#ref-list-1

Articles cited in:

http://genesdev.cshlp.org/content/13/3/270.full.htmI\#related-urls

License

Email Alerting Receive free email alerts when new articles cite this article - sign up in the box at the top

Service right corner of the article or click here.

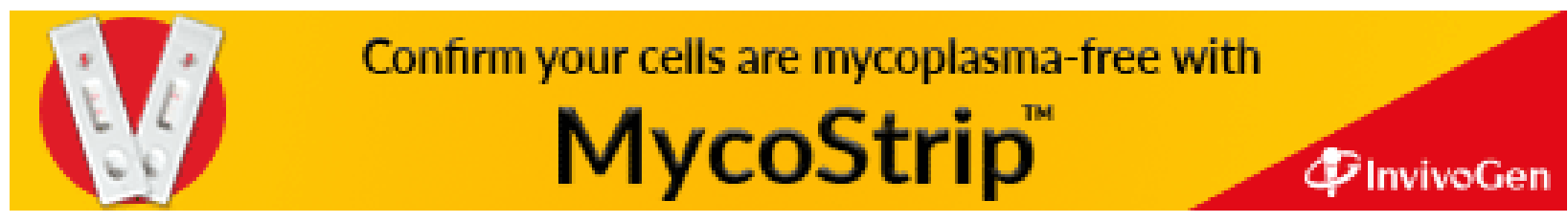

